\title{
ANOMÁLIE V POCHOVÁVANÍ NA STREDOVEKÝCH POHREBISKÁCH - PREJAV OKRAJOVÝCH SKUPÍN OBYVATELSTVA?
}

\author{
LUCIA NEZVALOVÁ
}

\begin{abstract}
Abstrakt: So začiatkom inhumačného pochovávania vo včasnom stredoveku sa popri ustálenom pohrebnom ríte začinajú na pohrebiskách vyskytovat' aj odchýlky. Zatial’ čo v drvivej väčšine hrobov sa od začiatku 9. storočia pochovávalo vo vystretej polohe na chrbte s rukami natiahnutými pozdĺz tela s orientáciou v smere západ-východ, určité percento hrobov vykazuje odlišnosti. Patria medzi ne jedinci pochovani na bruchu či boku, prípadne skrčenci a jedinci uložení v smeroch východ-západ a juh-sever, resp. sever-juh. Na to, prečo k takémuto pochovávaniu dochádzalo, existuje viacero hypotéz. Neštandardné hroby bývajú interpretované aj ako hroby cudzincov alebo z iných dôvodov v spoločnosti nie úplne akceptovaných jedincov. V príspevku sa zaoberáme takýmito hrobmi vyskytujúcimi sa na pohrebiskách juhozápadného Slovenska a Moravy od 9. po 12. storočie a pokúsime sa načrtnút' príčiny, pre ktoré boli jedinci takto uložení.
\end{abstract}

Kl'účové slová: pochovávanie - neštandardné polohy a orientácia - 9.-12. storočie.

\section{Anomalies in Burials in Medieval Burial Grounds: Manifestation of Marginalised Social Groups?}

\begin{abstract}
With the beginning of grave burials in the early Middle Ages, deviations started to appear along with the established rites. While in the overwhelming majority of graves from the early 9th century onwards people were buried stretched on their backs with arms placed along the body, in the west-east orientation, a certain percentage of graves shows differences. These include individuals buried lying on their stomach or side, in crouched position and those interred in the east-west, south-north and north-south orientations. There are several hypotheses explaining why these burials occurred. Non-standard graves are usually interpreted as graves of foreigners or other individuals that were socially excluded. This article discusses these graves found in the burial grounds of south-western Slovakia and Moravia from the 9th century until the 12th century, and outlines the reasons why some individuals were buried in this manner.
\end{abstract}

Key words: burial - non-standard positions and orientation - 9th-12th centuries.

\section{Úvod}

Štandardným hrobovým celkom sa vo včasnom stredoveku na území juhozápadného Slovenska a Moravy stáva od začiatku 9. storočia taký, v ktorom sa jedinec nachádza vo vystretej polohe na chrbte s rukami pozdĺž tela a orientáciou pochovaného v smere západ-východ (Hanuliak 2004, 44). Za prípustné sú tiež považované mierne pokrčenia horných aj dolných končatín, uloženie jednej alebo oboch rúk do panvy, prípadne ich umiestnenie na oblast' brušnej dutiny. Mierne pokrčenie končatín je pomerne častou odchýlkou, ktorá sa nepovažuje za vážne narušenie princípov pohrebného rítu (Hanuliak-Rejholcová 1999). Avšak zároveň s jej uplatňovaním sa vyskytujú aj výnimky, ktoré sa zo zaužívaného spôsobu vymykajú. Medzi neštandardné hrobové celky zarad'ujeme tie hroby a tých zomrelých jedincov, ktorí neboli pochovaní v pohrebných areáloch typických pre sledované obdobie (vidiecke radové pohrebiská, kostolné cintoríny, pohrebiská bez prítomnosti kostola na centrálnych lokalitách) a tiež jedincov, ktorí síce boli pochovaní v rámci pohrebného areálu, ale od štandardných hrobov sa odlišovali - či už svojou orientáciou (uloženie vo východo-západných, prípadne severo-južných smeroch), polohou (jedinci uložení v polohe na bruchu, na boku, prípadne zriedkavejšie nachádzaní aj v klačiacej alebo polosediacej polohe), alebo boli na telách vykonané postfunerálne zásahy (podl’a Štefan 2009, 140-142).

Príspevok sa pokúša interpretovat' práve anomálne hroby na plochých pohrebiskách na území Moravy a juhozápadného Slovenska v období 9.-12. storočia. Najväčšie zastúpenie majú pritom vidiecke pohrebiská, analyzované sú aj kostolné cintoríny, nekostolné cintoríny na centrálnych lokalitách a osamotené hroby. Ide o obdobie, v ktorom boli oba geografické regióny súčast'ou Vel'kej Moravy, o čas po jej zániku a dobu formovania včasnostredovekých štátov. V štúdii sa konkrétne zaoberáme jedincami uloženými v neštandardných polohách (na bruchu 
a na boku) a jedincami, ktorí boli neštandardne orientovaní. Tieto odchýlky od zvyčajného spôsobu pochovávania sa nachádzajú na viacerých pohrebiskách, nie sú teda ojedinelým javom. ${ }^{1}$ Pokúsime sa preto nájst' paralely medzi jednotlivými pohrebmi, ktoré by mohli naznačovat' určité vzory pri používaní jednotlivých polôh a mohli by napovedat', aké pohnútky viedli žijúcich k uloženiu nebožtíka do nezvyčajnej polohy.

Nezvyčajná pozícia alebo iná orientácia pochovaného bola zaznamenaná celkovo na 89 zo 155 analyzovaných pohrebísk (tab. 1). Na pohrebiskách (obr. 1), kde sa vyskytli odchýlky, bolo nájdených viac ako 11000 hrobov. Z toho v atypickej polohe bolo pochovaných 241 jedincov, opačnú orientáciu malo 696 hrobov (obr. 2). Dokopy registrujeme 724 hrobov s odchýlkou, čo tvorí približne osem percent zo všetkých hrobov. Ak by sme prirátali aj pohrebiská, na ktorých sa tieto anomálie nevyskytovali, podiel nezvyčajných hrobov na pohrebiskách predstavuje okolo $5 \%$. Hroby s opačnou orientáciou sme d’alej rozdelili na orientované v smere východ-západ (a ich odchýlkach) a orientované v severo-južných a juho-severných smeroch.

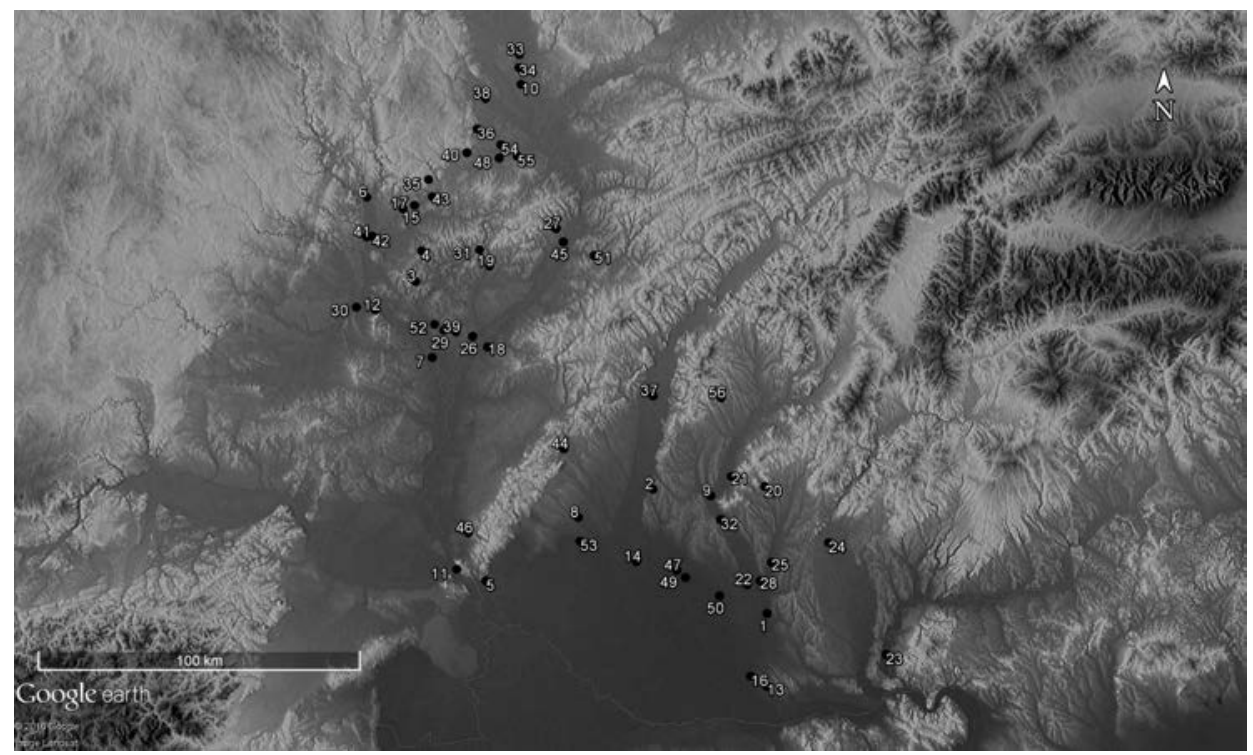

Obr. 1. Mapa s distribúciou anomálnych hrobov na území juhozápadného Slovenska a Moravy. 1 - Bešeňov, 2 - Bojničky, 3 - Boleradice, 4 - Bošovice, 5 - Bratislava, 6 - Brno, 7 - Břeclav, 8 - Cífer-Pác, 9 - Čakajovce, 10 - Čertoryje, 11 - Devín, 12 - Dolní Věstonice, 13 - Dolný Peter, 14 - Galanta, 15 - Holubice, 16 - Hurbanovo, 17 - Jiříkovice, 18 - Kopčany, 19 Kyjov, 20 - Ladice, 21 - Lefantovce, 22 - Lipová-Ondrochov, 23 - Malé Kosihy, 24 - Marušová, 25 - Michal nad Žitavou, 26 - Mikulčice, 27 - Modrá, 28 - Mojzesovo, 29 - Moravský Žižkov, 30 - Mušov, 31 - Nechvalín, 32 - Nitra, 33 - Olomouc, 34 - Olomouc-Nemilany, 35 - Olšany, 36 - Otaslavice, 37 - Pobedim, 38 - Prostějov, 39 - Prušánky, 40 - Pustiměř, 41 - Rajhrad, 42 - Rajhradice, 43 - Rousínov, 44 - Smolenice, 45 - Staré Město, 46 - Stupava, 47 - Šal'a-Veča, 48 - Tištín u Kojetína, 49 - Trnovec nad Váhom-Horný Jatov, 50 - Tvrdošovce, 51 - Veletiny, 52 - Vel'ké Bílovice, 53 - Vel'ký Grob, 54 - Víceměřice, 55 - Vitčice, 56 - Závada. Podklad Google Earth.

Abb. 1. Karte mit der Verteilung von anomalen Gräbern auf dem Gebiet der Südwestslowakei und Mährens. 1 - Bešeňov, 2 - Bojničky, 3 - Boleradice, 4 - Bošovice, 5 - Bratislava, 6 - Brno, 7 - Břeclav, 8 - Cífer-Pác, 9 - Čakajovce, 10 - Čertoryje, 11 - Devín, 12 - Dolní Věstonice, 13 - Dolný Peter, 14 - Galanta, 15 - Holubice, 16 - Hurbanovo, 17 - Jiříkovice, 18 - Kopěany, 19 - Kyjov, 20 - Ladice, 21 - Lefantovce, 22 - Lipová-Ondrochov, 23 - Malé Kosihy, 24 - Marušová, 25 - Michal nad Žitavou, 26 - Mikulčice, 27 - Modrá, 28 - Mojzesovo, 29 - Moravský Žižkov, 30 - Mušov, 31 - Nechvalín, 32 - Nitra, 33 Olomouc, 34 - Olomouc-Nemilany, 35 - Olšany, 36 - Otaslavice, 37 - Pobedim, 38 - Prostějov, 39 - Prušánky, 40 - Pustiměř, 41 - Rajhrad, 42 - Rajhradice, 43 - Rousínov, 44 - Smolenice, 45 - Staré Město, 46 - Stupava, 47 - Šal'a-Veča, 48 - Tištín u Kojetína, 49 - Trnovec nad Váhom-Horný Jatov, 50 - Tvrdošovce, 51 - Veletiny, 52 - Vel'ké Bílovice, 53 - Vel'ký Grob, 54 - Víceměřice, 55 - Vitčice, 56 - Závada. Vorlage Google Earth.

1 Jednotlivé pohrebiská a počty analyzovaných hrobov spolu s odkazmi na príslušnú literatúru, z ktorých som vychádzala pri písaní článku, sú uvedené v tabul'ke 1 na konci príspevku. Z týchto pohrebísk bola tiež vytvorená nepublikovaná databáza, z ktorej vychádzam aj pri uvádzaní jednotlivých údajov o hroboch a pochovaných jedincoch. 


\begin{tabular}{|c|c|c|c|c|c|c|c|}
\hline & $\begin{array}{c}\text { Celkový počet } \\
\text { jedincov }\end{array}$ & $\begin{array}{c}\text { Celkový počet } \\
\text { lokalit }\end{array}$ & \multicolumn{2}{c|}{ Morava } & Morava & $\begin{array}{c}\text { Juhozápadné } \\
\text { Slovensko }\end{array}$ & $\begin{array}{c}\text { Juhozápadné } \\
\text { Slovensko }\end{array}$ \\
\cline { 5 - 8 } & & Počet jedincov & Počet lokalít & Počet jedincov & Počet lokalít \\
\hline Poloha na bruchu & 34 & 17 & 24 & 8 & 10 & 9 \\
\hline Poloha na boku & 216 & 44 & 155 & 23 & 61 & 21 \\
\hline Orientácia V-Z & 432 & 66 & 275 & 38 & 157 & 28 \\
\hline Orientácia S-J & 264 & 55 & 206 & 35 & 58 & 20 \\
\hline
\end{tabular}

Obr. 2. Tabul'ka zobrazujúca pomer jednotlivých anomálií v hroboch na území juhozápadného Slovenska a Moravy.

Abb. 2. Tabelle mit Darstellung des Verhältnisses der einzelnen Anomalien in den Gräbern auf dem Gebiet der Südwestslowakei und Mährens.

\section{Neštandardná pozícia}

\section{Pozícia na bruchu}

Najmenšie percento hrobov $\mathrm{z}$ analyzovanej skupiny zaberajú hroby v polohe na bruchu. Na území juhozápadného Slovenska a Moravy bolo nájdených dokopy 35 jedincov z 19 pohrebísk (obr. 3). Na siedmich z nich bol zistený viac ako jeden jedinec uložený do hrobu v analyzovanej polohe (tab. 1), z toho v Rajhrade bolo takto pochovaných až 9 jedincov. Len na minime z pohrebísk prekračuje ich podiel $5 \%$ a vo väčšine prípadov nedosahuje ani $2 \%$.

Na pohrebiskách tieto hroby neboli izolované alebo inak výrazne odlíšené od zvyšku. Výnimku tvorí pohrebisko v Rajhrade, kde sa skupinka piatich hrobov s jedincami v polohe na bruchu spolu s hrobmi s pochovanými v pozícii na boku koncentrovala na západe strednej časti pohrebiska severne od žlabu, ktorý môže byt' pozostatkom po ohraničení staršej časti pohrebiska (Staňa 2006, 34). V hroboch neboli zaznamenané žiadne zvláštne úpravy. Ak bolo možné rozoznat' tvar hrobovej jamy, išlo vždy o obdĺžnik so zaoblenými rohmi a kolmými stenami. Jedine na pohrebisku v Uherskom Hradišti-Sadoch, Horních Kotvicích boli pod kostrou nájdené stopy po drevenej

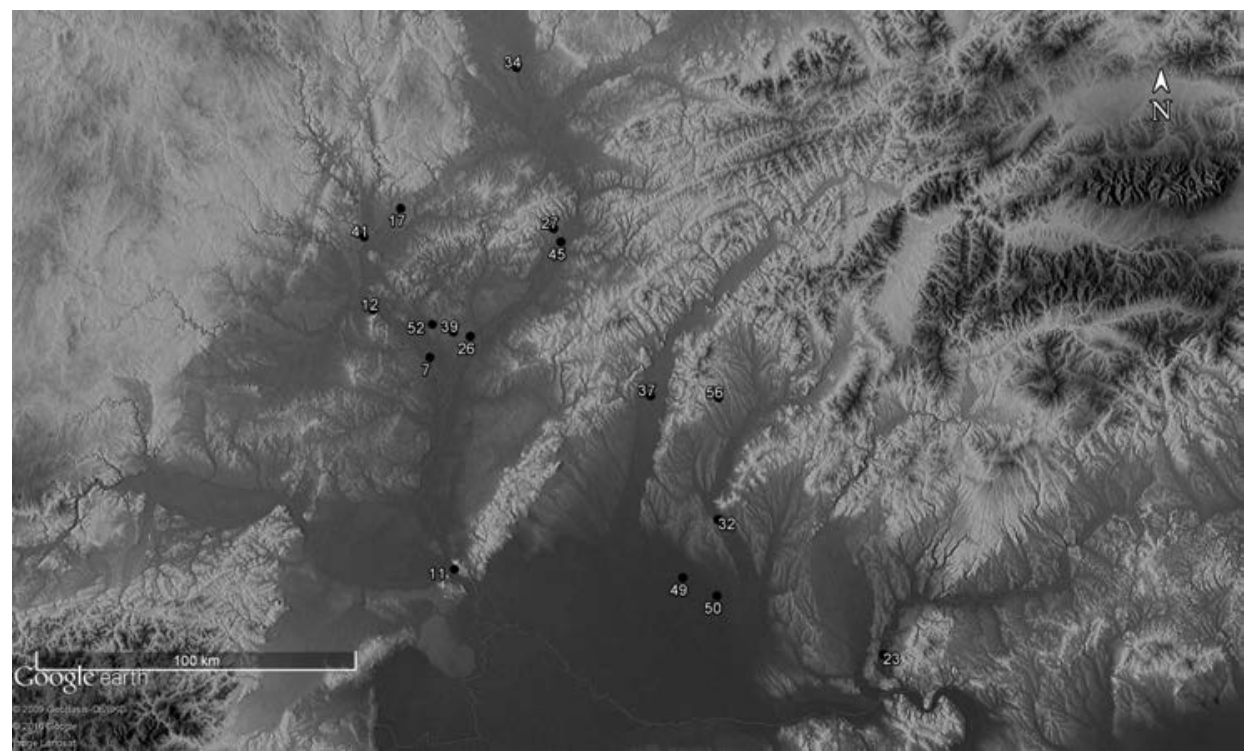

Obr. 3. Mapa pohrebísk s jedincami nájdenými v polohe na bruchu. Číslovanie jednotlivých lokalít zodpovedá číslu priradenému lokalite na obr. 1. Podklad Google Earth.

Abb. 3. Karte der Gräberfelder mit in Bauchlage bestatteten Individuen. Die Nummerierung der einzelnen Fundstellen entspricht jeweils der Nummer der in Abb. 1 zugeordneten Fundstellen. Vorlage Google Earth. 
podložke (Marešová 1983, 26). Poloha jedincov tiež nebola unifikovaná. Celkové uloženie nebožtíka v niektorých hroboch nasvedčuje skôr tomu, že telo bolo do jamy vhodené, nie pietne uložené.

Vo väčšine hrobov prevláda orientácia kostrových pozostatkov v smere západ-východ, prípadne evidujeme od nej odchýlky smerom k juhozápadu alebo severozápadu, ktoré nie sú považované za nezvyčajné. Šest' hrobov bolo orientovaných neregulárne, vo východo-západných smeroch boli uložení pochovaní v štyroch hroboch, v severo-južných v dvoch.

V analyzovaných hroboch výrazne dominujú ženy oproti mužom (graf 1). Ženy sa nachádzali v 16 hroboch, mužov evidujeme v siedmich hroboch. U 12 jedincov nebolo určené pohlavie. Rovnaký stav je aj v Čechách (Štefan 2009, 148). V Pol’sku a Škandinávii je situácia opačná, dominujú na bruchu uložení muži, deti neboli v tejto polohe nájdené (Gardela 2011, 49).

Na základe určenia veku v súbore mierne dominujú ôsmi jedinci pochovaní v intervale medzi 30 a 40 rokmi, nasledujú piati, ktorí zomreli medzi 50 a 60 rokmi (graf 2). Avšak vzhl'adom na celkovo nízky počet nájdených jedincov, z ktorých vo všetkých prípadoch nebol stanovený vek úmrtia, tento údaj sa nedá považovat' za smerodajný. Za povšimnutie však stojí skutočnost', že medzi takto pochovanými bolo nájdené len jedno diet’a (v hrobe 308 v Prušánkach, Klanica 2006, 175). To môže naznačovat', že dôvody pre pochovanie jedinca na bruchu mohla komunita nájst' vo vedomých akciách človeka počas jeho života, teda v dobe, odkedy bol považovaný za plnoprávneho člena spoločnosti.

Hrobový inventár bol nájdený len v štyroch hroboch z celkového počtu 35 . K hrobom s výbavou tiež môžeme pripočítat' hrob 214 z Rajhradu, kde sa na lebke nachádzala zelená patina, ktorú tam pravdepodobne zanechala bronzová náušnica (Staňa 2006, 65). Jednoduchá bronzová náušnica s nádobou bola nájdená vo Velkých Bíloviciach (hrob 51, Měřínský 1985, 113). Na pohrebisku v Prušánkách v hrobe 188 (Klanica 2006, 142) mal jedinec v hrobe medený krúžok a črep, na tom istom pohrebisku v hrobe 308 boli zvieracie kosti (Klanica 2006, 176), v Modré u Velehradu boli

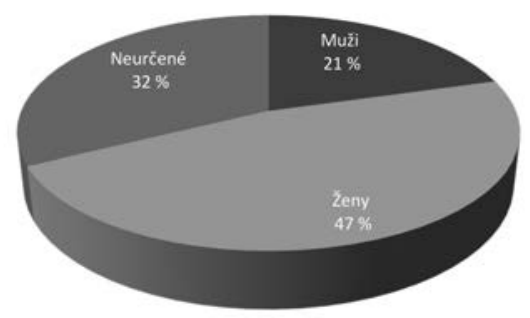

Graf 1. Zastúpenie jedincov rozdielneho pohlavia uložených v polohe na bruchu.

Diagramm 1. In Bauchlage vertretene Individuen unterschiedlichen Geschlechts.

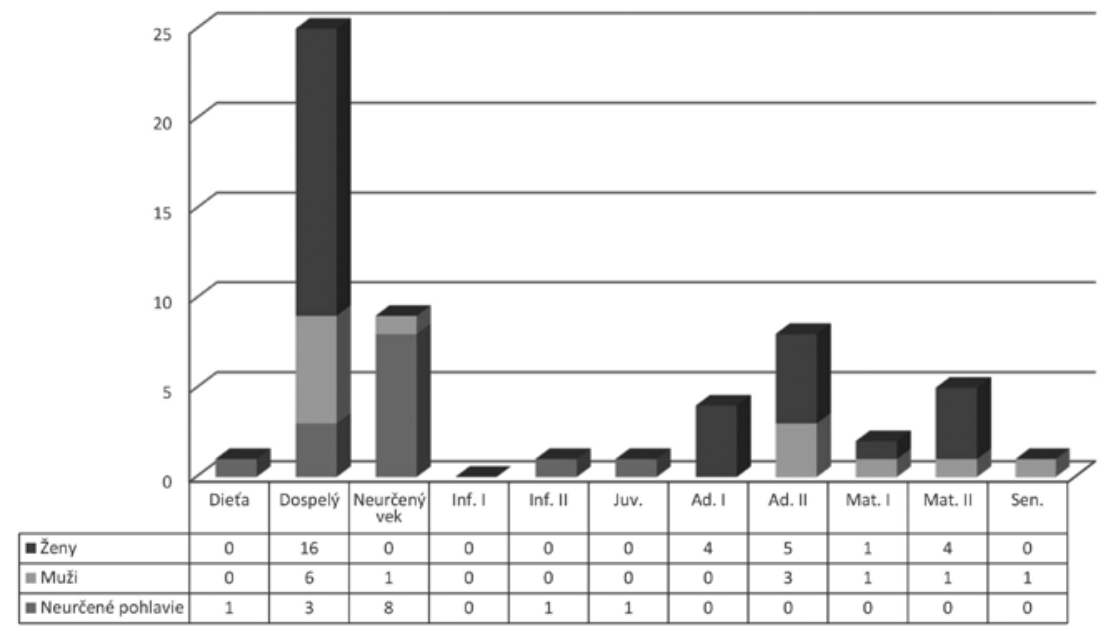

Graf 2. Zastúpenie jedincov rozdielneho pohlavia a veku uložených v polohe na bruchu.

Diagramm 2. In Bauchlage vertretene Individuen unterschiedlichen Geschlechts und Alters. 
v zásype hrobu 11/53 nájdené štyri črepy (Hrubý-Hochmanová-Pavelčík 1955, 71). Tieto typy predmetov nepatria medzi prestížny inventár, nie sú to zbrane či ostrohy, alebo náročne vypracované šperky. Tento jav je spoločný aj pre takéto hroby v Čechách (Štefan 2009, 146) a Pol’sku, či Škandinávii (Gardela 2011, 49). Ked’že hroby majú minimálnu alebo žiadnu výbavu, je náročné presnejšie ich datovat'. Často ich môžeme určit' len rámcovo podl'a obdobia trvania pohrebiska.

\section{Pozícia na boku}

Pozícia na boku bola na 44 analyzovaných lokalitách zaznamenaná celkovo v 216 prípadoch (obr. 4, tab. 1). Skúmaní boli jedinci uložení na boku vo vystretej až extrémne skrčenej polohe. $\mathrm{Z}$ toho 100 jedincov bolo uložených na l'avom boku a 116 na pravom. Dvadsat’jeden nálezísk sa nachádza na území juhozápadného Slovenska, 23 na území Moravy. Väčšinové zastúpenie majú pohrebiská, tri sú kostolné cintoríny a v jednom prípade to bol osamotený hrob. Hoci sú nálezy jedincov v polohe na boku početnejšie ako v polohe na bruchu, ani tieto hroby nemajú výrazný podiel medzi hrobmi. Vo väčšine prípadov ich podiel nedosahuje ani $5 \%$.

Tak ako v prípade jedincov na bruchu, je táto poloha pripisovaná nebožtíkom potenciálne nebezpečným, ktorí mohli škodit' živým (Ungerman 2007, 61). Ich vylúčenie zo spoločnosti či možné ohrozovanie pozostalých by mohla potvrdit' aj ich pozícia v rámci jednotlivých pohrebísk. Hroby sú väčšinou, s výnimkou niektorých hrobov z Rajhradu (Staňa 2006, 34), ukladané pomedzi regulárne hroby. Ak je na pohrebisku prítomných viac takýchto hrobov, nekoncentrujú sa na jednom mieste. Hroby s neštandardne uloženými jedincami väčšinou neboli zvláštne upravované. Úpravy či stopy po úpravách sa vyskytli v 12 prípadoch, nešlo však o zložité konštrukcie.

$\mathrm{V}$ orientácii tiel pochovaných vzhl'adom na svetové strany dominovali západo-východné smery, v týchto smeroch boli uložení nebohí v takmer polovici prípadov (96). Vo východo-západných smeroch, teda opačne, bolo nájdených 26 jedincov, v severo-južnej ,„priečnej“ orientácii to bolo 23 jedincov. Ich pomer je teda prakticky vyrovnaný. V zvyšných 71 prípadoch nebolo možné orientáciu zistit', pretože nebola uvedená, prípadne nebol publikovaný katalóg hrobov.

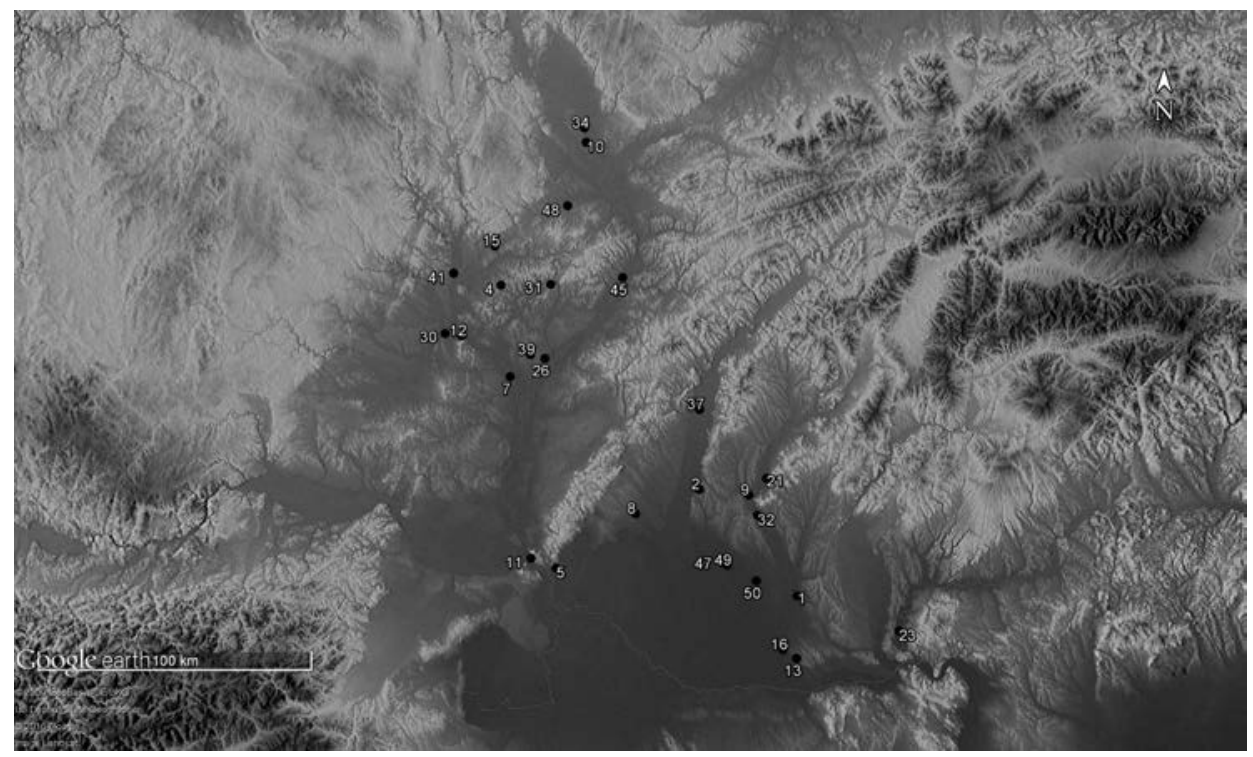

Obr. 4. Mapa lokalít s nájdenými jedincami uloženými v polohe na boku. Číslovanie jednotlivých lokalít zodpovedá číslu priradenému lokalite na obr. 1. Podklad Google Earth.

Abb. 4. Karte der Fundstellen mit in Seitenlage bestatteten Individuen. Die Nummerierung der einzelnen Fundstellen entspricht jeweils der Nummer der in Abb. 1 zugeordneten Fundstellen. Vorlage Google Earth. 
Všeobecne sa však neštandardná orientácia vyskytuje častejšie u jedincov pochovaných na boku než u pochovaných v zvyčajnej polohe.

Pri určení pohlavia nie je rozdiel medzi mužmi a ženami tak výrazný ako pri jedincoch uložených v polohe na bruchu (graf 3). Takto pochovaných žien bolo 35, mužov 22 . Pohlavie však nebolo stanovené u takmer troch štvrtín nálezov, takže z týchto počtov nie je možné vychádzat' pri interpretácii hrobov.

Rovnako vek bol stanovený len v 115 prípadoch, z toho v 31 z nich to bolo len približné vekové určenie (dospelý, diet’a), bez spresnenia na zaužívané antropologické kategórie (inf., juv., ad., mat., sen.). Pomer dospelých k det’om je, na rozdiel od jedincov uložených v polohe na bruchu, pomerne vyrovnaný (graf 4). Dospelých bolo nájdených 67, detí 48, pričom k dospelým boli zarátaní jedinci vo veku od 14 rokov, vrátane. Hrobový inventár bol nájdený v 56 hroboch, čiže približne v štvrtine z nich.

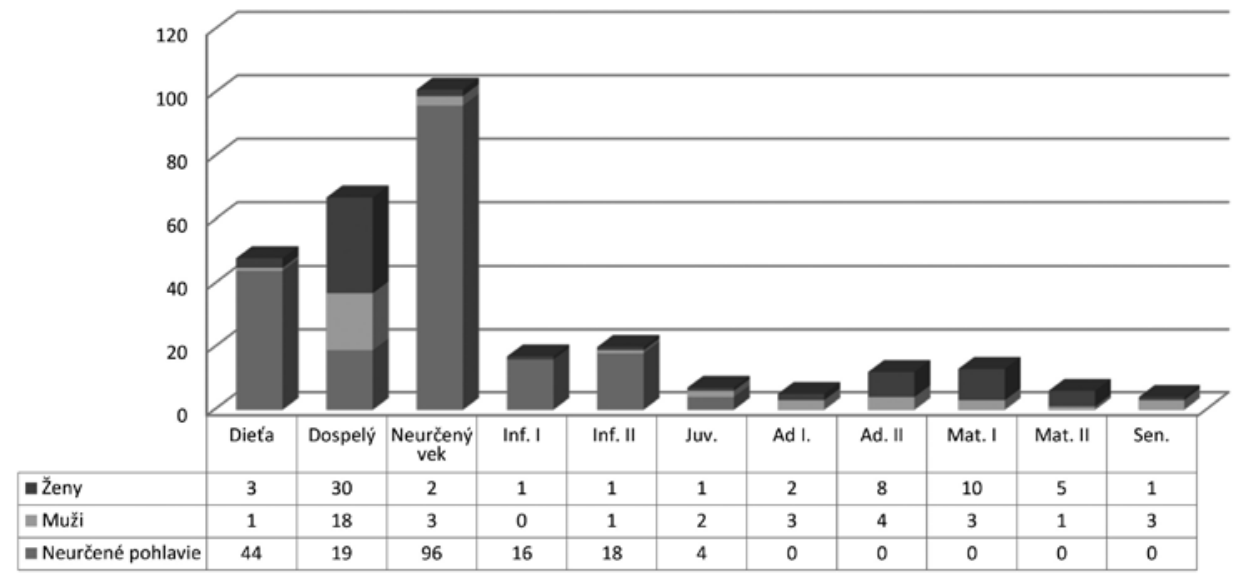

Graf 4. Zastúpenie jedincov rozdielneho pohlavia a veku uložených v polohe na boku.

Diagramm 4. In Seitenlage vertretene Individuen unterschiedlichen Geschlechts und Alters.

\section{Neštandardná orientácia}

Odchýlky v orientácii sa oproti nezvyčajným polohám vyskytujú na pohrebiskách častejšie, celkovo sme zaznamenali 696 prípadov. Za regulárnu orientáciu bola pre sledovaný súbor považovaná orientácia v smere západ-východ a jej prilahlé varianty (JZ-SV, ZJZ-VSV, ZSZ-VJV, SZ-JV), tieto sa na pohrebiskách vyskytujú najčastejšie (k orientácii napríklad Hanuliak 2004, 111), pričom odchýlky od základného západo-východného smeru záviseli od faktorov, ako napríklad konfigurácia terénu, hlavná os tela však mala smerovat’ do záhrobia (Hanuliak 2004, 112). Za hroby s neregulárnou orientáciou boli preto považované hroby, v ktorých jedinci boli orientovaní proti tomuto smeru (v smeroch V-Z, VSV-ZJZ, VJV-ZSZ, SV-JZ, JV-SZ) alebo priečne voči väčšine hrobov na pohrebiskách (azimuty S-J, J-S, SSZ-JJV, SSV-JJZ, JJV-SSZ, JJZ-SSV). Jedinci orientovaní v severo-južných smeroch bývajú označovaní ako cudzinci, otroci či inoverci, teda príslušníci okrajových skupín obyvatel'stva (Hanuliak 2004, 112). Opačný smer pochovávania ako možné diskriminačné opatrenie prezentovala pre avarské pohrebiská I. Kovrig $(1963,102)$. 
Na 52 pohrebiskách dosahuje podiel týchto hrobov $10 \%$ a menej. Hroby s odlišnou orientáciou sa objavujú aj na pohrebiskách, kde predtým spomínané hroby s jedincami uloženými v neregulárnych polohách neboli nájdené. V prípade anomálnej orientácie rozlišujeme dve základné odchýlky. Menej početná je orientácia v južných a severných smeroch, pri ktorej sú hroby smerované v podstate naprieč k všeobecnému smeru hrobovej jamy. Častejšie sa objavujú východné azimuty.

\section{a) Odchýlky v orientácii v smere juh-sever a sever-juh}

V smere sever-juh, juh-sever a pril'ahlých azimutoch evidujeme celkovo 264 pochovaných jedincov (obr. 5). Tak ako pri hroboch v polohe na bruchu a na boku, nevystúpili pri hroboch v orientácii s hlavou na sever či na juh špecifiká. Hroby na pohrebiskách neboli izolované, ani sa nekoncentrovali v niektorej ich časti. Niektoré z nich boli dokonca upravené, jedinci boli uložení napríklad v rakve (Bednár 1997, 29), alebo boli nájdené stopy po drevenej konštrukcii (Chropovský 1957, 177-179).

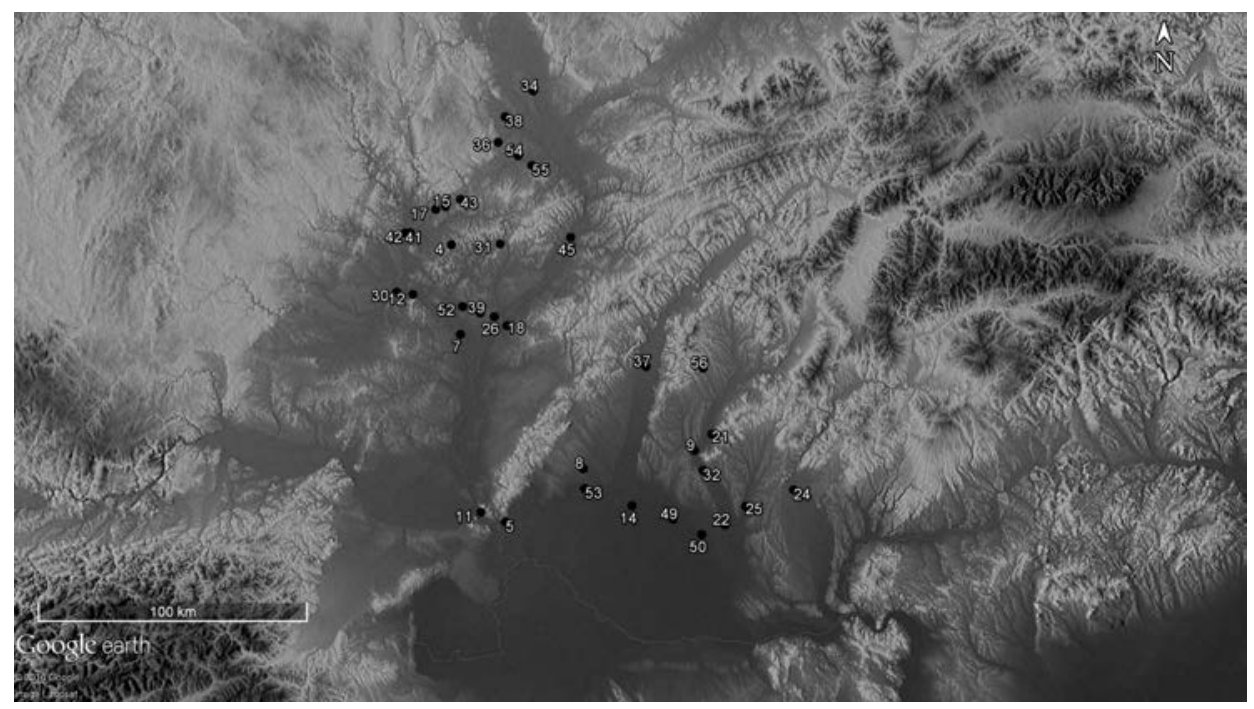

Obr. 5. Mapa lokalít s jedincami pochovanými v severných a južných smeroch. Číslovanie jednotlivých lokalít zodpovedá číslu priradenému lokalite na obr. 1. Podklad Google Earth.

Abb. 5. Karte der Fundstellen mit in Nord- und Südrichtung bestatteten Individuen. Die Nummerierung der einzelnen Fundstellen entspricht jeweils der Nummer der in Abb. 1 zugeordneten Fundstellen. Vorlage Google Earth.

Pomer pohlaví je pri orientácii v smere sever-juh a juh-sever vyrovnaný, ked’že $\mathrm{v}$ tejto polohe registrujeme 40 žien a 36 mužov (graf 5). To však predstavuje príliš nízky počet z celkového počtu hrobov, ktorý spôsobuje, že údaje nemožno považovat' za smerodajné. Rovnako je to aj v prípade veku, ked' 119 jedincov nemalo určené vekové kategórie (graf 6). Ďalších 46 jedincov bolo označených len ako dospelý/dieta. V tejto orientácii bolo nájdených 58 detí a 87 dospelých, dominujú teda dospelí. Relatívne najviac jedincov (29) však patrilo do kategórie inf. I, ${ }^{2}$ čiže do 7 rokov.

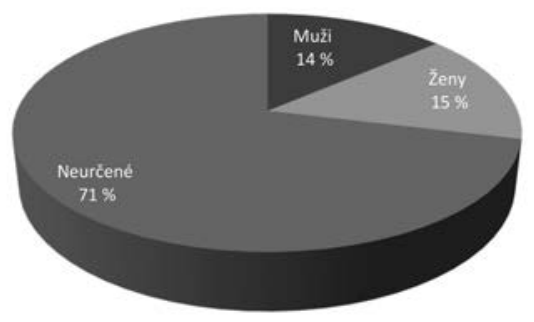

Graf 5. Zastúpenie jedincov rozdielneho pohlavia uložených v severo-južných smeroch.

Diagramm 5. In Nord-Süd-Richtung vertretene Individuen unterschiedlichen Geschlechts.

2 Rozdelenie podl'a Stloukal 1999, 236. 


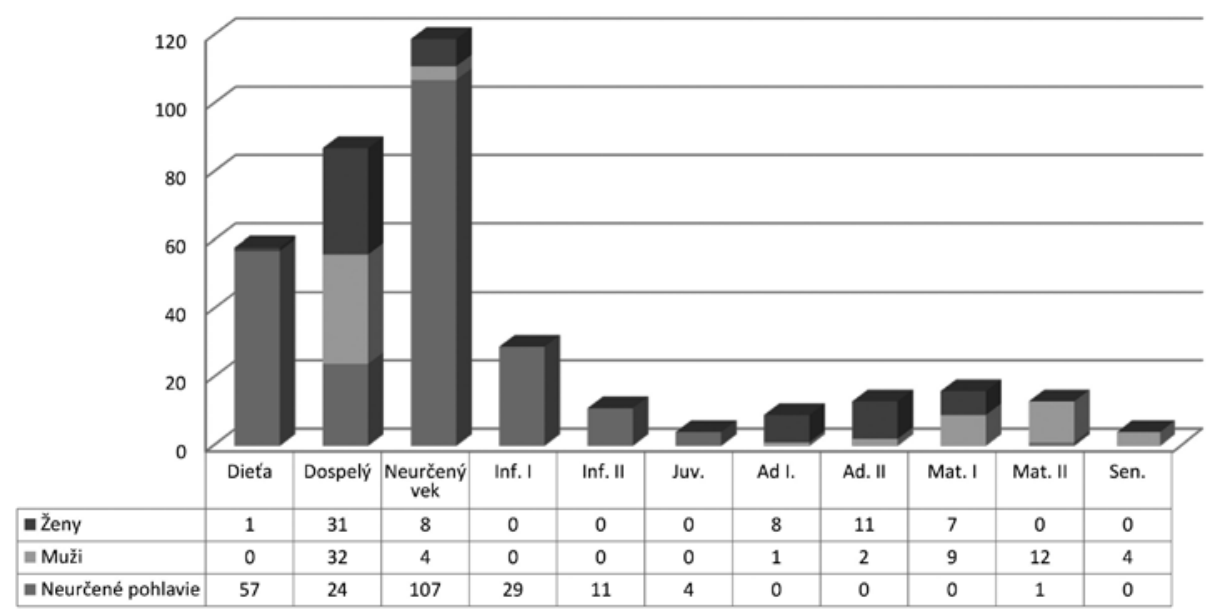

Graf 6. Zastúpenie jedincov rozdielneho pohlavia a veku uložených v severo-južných smeroch.

Diagramm 6. In Nord-Süd-Richtung vertretene Individuen unterschiedlichen Geschlechts und Alters.

Druhú najpočetnejšiu kategóriu tvoria zomretí vo veku maturus I (16), teda medzi 40-50 rokmi. Za povšimnutie stojí, že zatial' čo v mladších vekových kategóriách sú v severných a južných smeroch uložené hlavne ženy, v neskoršom veku prevládajú muži (obr. 11). Zlomový je pritom vek medzi 40 a 50 rokmi (kategória maturus I). Je však otázne, či by sa tento trend potvrdil aj v prípade, že by bol vek určený pri viacerých jedincoch.

Hrobový inventár bol nájdený v 101 hroboch s jedincami pochovanými v severo-južnej orientácii, teda v necelých $40 \%$, čo je o niečo menej, ako býva všeobecne na pohrebiskách (pre porovnanie Hanuliak 2004a, 123). Zastúpenie predmetov bolo rôzne, čo do početnosti aj zloženia. Najčastejšie boli nachádzané nože (43 hrobov) a nádoby (39 hrobov), prípadne ich fragmenty (9 hrobov). Výbavu väčšinou tvoril jeden, prípadne dva alebo tri predmety. Častá bola kombinácia noža s nádobou, prípadne s iným predmetom.

\section{b) Jedinci orientovaní v smere východ-západ a jeho variantoch}

V smere východ-západ a pril’ahlých azimutoch bolo pochovaných 432 jedincov na 66 lokalitách (obr. 6). Z toho 38 nálezísk s 275 jedincami sa nachádza na Morave a 28 so 157 jedincami na Slovensku. Štyri predstavujú kostolné cintoríny, jeden bol osamotený hrob, zvyšok sú pohrebiská (tab. 1). Takisto ako v prípade hrobov orientovaných v severo-južných smeroch, hroby v orientácii východ-západ neboli nijak vyčlenené v rámci areálu pohrebiska. V uvedenej kategórii boli úpravy hrobových jám zistené v 46 prípadoch.

Dominantná poloha u jedincov uložených vo východo-západnom smere a jeho variantoch bola natiahnutá, vyskytli sa však aj polohy na bruchu a boku. Ženy s touto orientáciou boli v 72 hroboch, muži v 73 hroboch, pomer je teda vyrovnaný (graf 7). Tak ako v predošlých prípadoch neregulárnych hrobov však vo väčšine hrobov (287) nebolo určené pohlavie. Vek nebol stanovený u takmer polovice (171) jedincov, d’alších 71 hrobov bolo zaradených len do kategórie diet’a/dospelý (graf 8). Pomer medzi det'mi (122 jedincov) a dospelými (139 jedincov) je tiež pomerne vy-

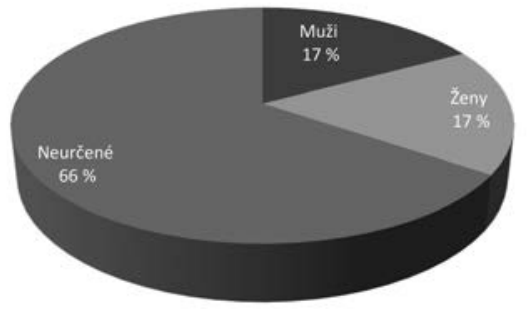

Graf 7. Zastúpenie jedincov rozdielneho pohlavia uložených vo východo-západnom smere.

Diagramm 7. In Ost-West-Richtung vertretene Individuen unterschiedlichen Geschlechts. 


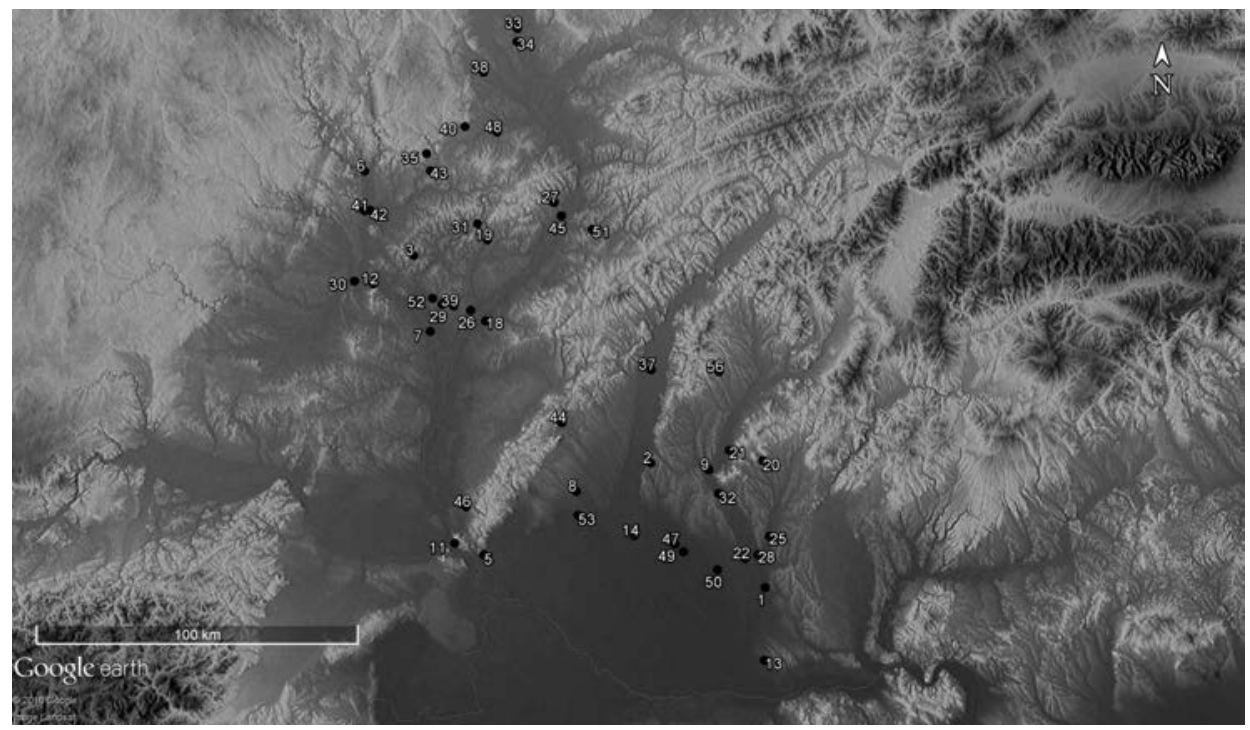

Obr. 6. Mapa lokalít s jedincami pochovanými vo východo-západných smeroch. Číslovanie jednotlivých lokalít zodpovedá číslu priradenému lokalite na obr. 1. Podklad Google Earth.

Abb. 6. Karte der Fundstellen mit in Ost-West-Richtung bestatteten Individuen. Die Nummerierung der einzelnen Fundstellen entspricht jeweils der Nummer der in Abb. 1 zugeordneten Fundstellen. Vorlage Google Earth.

rovnaný. Najviac jedincov bolo vo vekovej skupine inf. I (deti do 7 rokov), do tejto skupiny bolo zaradených až 69 pochovaných, čo je výrazne vyšší počet ako v ostatných skupinách. Druhú najpočetnejšiu skupinu predstavovali pochovaní vo veku Ad. II - 29 jedincov a Mat. I - 28 jedincov.

Hrobový inventár evidujeme v 176 hroboch. Medzi najčastejšie nachádzaný inventár patrili predmety, ktoré sa frekventovane objavujú vo včasnostredovekých hroboch - nože (74 hrobov), nádoby ( 60 hrobov). Zo šperkov evidujeme najčastejšie náušnice ( 44 hrobov). U jedincov pochovaných v opačných smeroch sa tiež vyskytli hroby s výbavou, ktorú je možné považovat' za nadštandardnú. Napríklad v hrobe 788 na pohrebisku v Čakajovciach (Rejholcová 1995, 88) boli zistené nôž, kosák, sekera bradatica, kovanie vedierka, ostrohy, pracky, jazykovité nákončia a rámčekové prevliečky. Hrob teda obsahuje atribúty, ktoré bývajú pripisované mužom - bojovníkom.

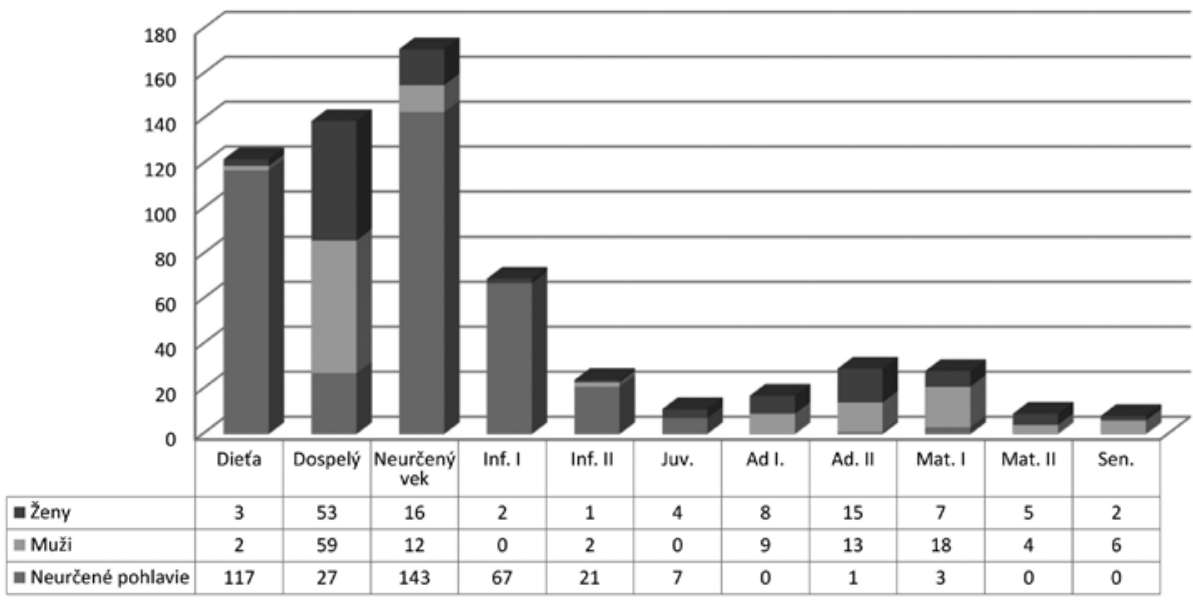

Graf 8. Zastúpenie jedincov rozdielneho pohlavia a veku uložených vo východo-západnom smere.

Diagramm 8. In Ost-West-Richtung vertretene Individuen unterschiedlichen Geschlechts und Alters. 


\section{Jedinci s fyzickými anomáliami alebo chorobami}

Na mnohých pohrebiskách chýbajú antropologické analýzy, prípadne sa obmedzujú len na určenie veku a pohlavia jednotlivcov. $Z$ dostupných údajov o neštandardných hroboch však neboli zistené takmer žiadne na kostre pozorovatel'né telesné defekty alebo choroby, ktoré by mohli ovplyvnit' pochovanie jedinca $v$ zvláštnej polohe. Absencia patológií a znakov choroby sa pri neregulárnych hroboch potvrdzuje všeobecne $\mathrm{v}$ širších časových aj geografických kontextoch (Aspöck 2008, 28). Najčastejšie uvádzaným ochorením bola spondylóza, ktorá je u stredovekých populácií vel’mi frekventovane sa vyskytujúcim ochorením (Horáčková-Vargová-Strouhal 2004, 45). Spôsobuje degeneratívne zmeny na chrbtici a podla stupňa postihnutia môže byt' sprevádzaná bolest'ou.

V hroboch 24 a 31 v Závade, kde bol jeden z jedincov uložený na bruchu a druhý bol orientovaný v smere východ-západ, boli zistené mongoloidné znaky. V oboch prípadoch šlo pravdepodobne o ženy (Bialeková 1982, 136). Mongoloidné znaky sa však vyskytli aj u d’alších deviatich jedincov z tohto pohrebiska, ktorí boli pochovaní regulárnym spôsobom.

$\mathrm{K}$ bežným nálezom na pohrebiskách patria cribra orbitalia, ,jedná se o kostní destrukci a kostni novotvorbu v prední části stropu očnice ve formě malých okrskůs pórovitou, případně houbovitou strukturou" (Horáčková-Vargová-Strouhal 2004, 145-146). Stopy po cribra orbitalia boli zistené len u anomálne pochovaných jedincov v Rajhrade (Hanáková-Staňa-Stloukal 1986) a v Mikulčiciach-Klášteřisku (Stloukal-Hanáková 1985). Ich výskyt býva popisovaný najčastejšie ako prejav poruchy výživy, a to bud' ako následok hypovitaminózy $\mathrm{C}$, alebo nedostatku železa v krvi, či jeho zlej absorpcie v dôsledku črevných ochorení. Tiež by mohli byt' dôsledkom dlhodobého hladovania (Horáčková-Vargová-Strouhal 2004, 146), čo by poukazovalo na jedincov nachádzajúcich sa $\mathrm{v}$ chudobnejších vrstvách spoločnosti. V Rajhrade cribra orbitalia registrujeme u deviatich jedincov zo 46 anomálne pochovaných, z toho pät' ich bolo pochovaných na boku a d’alší štyria boli orientovaní v južných a severných smeroch. Na druhej strane cribra orbitalia boli zistené aj u d’alších 55 jedincov, ktorí boli pochovaní štandardne. Analogickú situáciu dokladujeme aj v Mikulčiciach-Klášteřisku. Tam bolo nájdených šest’ neregulárne pochovaných jedincov s cribra orbitalia. Jeden jedinec bol položený na pravom boku, zvyšní boli orientovaní v severných a južných smeroch. Aj tu však bolo d’alších 30 jedincov s cribra orbitalia pochovaných regulárne. Domnievame sa preto, že výskyt cribra orbitalia a možný nedostatok výživy nepredstavoval významný faktor pri rozhodovaní o tom, ako jedinca pochovat'.

Na pohrebisku v Rajhrade bol objavený ešte jeden jedinec, ktorého fyzický vzhl'ad mohol ovplyvnit' jeho uloženie na l'avom boku. V hrobe 94 boli preskúmané kostrové pozostatky muža zomretého vo veku 20-30 rokov, ktorý trpel špecifickou spondylitídou bedrovej chrbtice a ostrouhlým hrbom (Hanáková-Staňa-Stloukal 1986, 69). Jedinec mal mat' teda v čase pohrebu hrb, ktorý však na základe fotografie (Staňa 2006, tab. VII:7) nepôsobí vel’mi výrazne. Nemožno však vylúčit, že jeho vzhl'ad ovplyvnil spôsob jeho uloženia v hrobe tým, že nebolo možné ho uložit' vo vystretej polohe, alebo ho práve pre fyzickú odlišnost' uložili na bok zámerne. Paralelu k pochovanému $\mathrm{z}$ hrobu 94 nachádzame na tom istom pohrebisku. V hrobe 170 rajhradského pohrebiska bol pochovaný jedinec, pravdepodobne mužského pohlavia, vo veku 15-16 rokov, ktorý trpel tiež spondylitídou dolnej hrudnej chrbtice s následným hrbom a dextroskoliózou, a zároveň bol uložený na lavom boku (Hanáková-Staňa-Stloukal 1986, 73).

V dvoch hroboch na pohrebisku v Bešeňove (hroby 11 a 28), poloha Papföld, zaznamenávame na lebkách pochovaných trepanačné otvory, pričom obaja jedinci boli uložení v smere východ-západ. Išlo o muža vo veku maturus a ženu vo veku juvenis (Szöke-Nemeskeri 1954, 116). Je však potrebné upozornit' na fakt, že na pohrebisku v Bešeňove boli vo východo-západnom smere uložené takmer všetky hroby, čiže jedinci s trepanáciou sa vlastne zo štandardného pochovávania na tomto pohrebisku nevymykajú.

Ďalší príklad, kedy fyzické deformity mohli ovplyvnit’ neregulárnost' pohrebu, registrujeme na pohrebisku v Starom Městě, polohe na Valách. Pochovaný jedinec mužského pohlavia vo veku 20 rokov (hrob 11/50) mal l'avú stehennú kost' o 8 centimetrov kratšiu ako pravú, takže je 
pravdepodobné, že počas života kríval. Bol uložený v smere VSV-ZJZ v natiahnutej polohe bez inventára (Hrubý 1955, 469).

Za zmienku stojí tiež jedinec z Malých Kosíh (hrob 90), položený v skrčenej polohe na l'avom boku v orientácii ZSZ-VJV (Hanuliak 1994, 106). Pochovaný mal sečné rany na záhlaví a pravej temennej kosti, ktoré boli pre neho smrtel'né (Vondráková-Hanuliak 2006, 369, 370). Tento zásah naznačuje, že muž mohol byt' potrestaný za svoj čin, alebo mohlo íst' o cudzieho narušitel'a. To by evokovalo, že do tejto polohy bol uložený v dôsledku trestu za svoje činy, a teda dôsledkom anomálneho uloženia tela boli činy vykonané jednotlivcom počas života.

Na základe týchto poznatkov môžeme usúdit', že deformácie a patologické javy zistitel'né u jedincov na kostre pravdepodobne v drvivej väčšine analyzovaných hrobov nehrali dôležitú úlohu pri rozhodovaní o ich neštandardnom uložení do hrobu. V takmer všetkých prípadoch môžeme nájst' jedincov s rovnakými anomáliami pochovaných na konkrétnom pohrebisku aj regulárnym spôsobom. V archeologickom materiáli absentuje zjednocujúci prvok, ked' u jedincov so spomínanými fyzickými znakmi, u ktorých sa uplatňuje neštandardné pochovanie bez postrehnutel'ného systému, chýba jednotné opatrenie, ktoré by ich spájalo.

\section{Vyhodnotenie}

Na základe uvedených poznatkov nebolo možné v prípade neštandardných hrobov identifikovat' určité vzory či schémy (okrem jedincov pochovaných v polohe na bruchu), od ktorých by sa dali odvodit' dôvody pre pochovanie v neregulárnej polohe. Preto sa domnievame, že každý prípad anomálneho hrobu je potrebné posudzovat' samostatne a v kontexte daného pohrebiska, na ktorom bol jedinec nájdený. Zároveň musíme rátat's tým, že príčinu uloženia $v$ danej polohe sa nám vo väčšine prípadov nepodarí odhalit' a že pri interpretácii neštandardných hrobov sa pohybujeme na vel'mi neistej pôde. Za zamyslenie stojí postreh E. Aspöck (2008), ktorá vo svojej štúdii o neštandardných hroboch konštatuje, že v stredoeurópskej archeológii je tendencia pokladat' ich za hroby tzv. nebezpečných mítvych (Aspöck 2008, 21).

Poloha na bruchu bola ako jedno z mála opatrení spomínaná aj v niektorých historických a etnografických prameňoch. V období cholerových epidémií ukladali mŕtvych do polohy na bruchu aj z preventívnych dôvodov. Počas epidémie l’udí, dobytka alebo inej tragickej udalosti mohli pozostalí otvorit' hrob nedávno pochovaného a mŕtvolu obrátit' dolu tvárou (Hoššo 1975, 158). Ešte v 20. storočí boli v polohe tvárou do zeme pochovávaní jedinci považovaní za upírov (Mjartan 1953, 115). Vzhl'adom na značnú časovú vzdialenost' od obdobia, ktoré skúmame v tomto príspevku, sa naskytá otázka, či je vôbec možné, aby tento zvyk pretrval dlhé stáročia a akými a kol'kými transformáciami v tejto dobe prešiel. Ked’že slovo vampír má novoveký pôvod (Hanuliak 2004a, 115) a povery súvisiace s ním sa vyskytujú tiež až od tohto obdobia, je možná aj iná interpretácia tohto javu. Na analyzovanom území, bohužial', nemáme zachované písomné pramene z daného obdobia, ktoré by sa vyjadrovali k pohrebným zvykom. Existujúce pramene sú značne vzdialené, či už časovo, alebo priestorovo. Na základe správy o pohrebe Pipina Krátkeho, ktorý ležal na kríži s tvárou nadol ako znak pokánia (Štefan 2009, 156), je možná s nastupujúcim krest’anstvom aj táto hypotéza.

Hlavne v prípade jedincov, ktorí vyzerali byt' do jamy pohodení (napríklad v Závade hrob 24, Bialeková 1982, 134), môžeme uvažovat' o nedbalom či rýchlom pohrebe, ktorý mohol byt' spôsobený bud' nízkym sociálnym statusom jednotlivca, alebo nedbanlivostou pozostalých.

$\mathrm{V}$ rámci danej problematiky stojí za zmienku hrob nájdený na pohrebisku v Tetíne (Kubálek-Stolz-Sasková-Vaněk 2008). Bol v ňom uložený jedinec v polohe na bruchu, ktorý mal zdravotný hendikep, ked’že bol pravdepodobne narodený už s rázštepom lebky (Kubálek-StolzSasková-Vaněk 2008, 648-649). Zo zdravotného hladiska jedinec určite vyžadoval špeciálnu starostlivost' kvôli vysokej pravdepodobnosti zranenia a infikovania, ked'že sa dožil pomerne vysokého veku (ad. I, 20-30 rokov). Túto deformáciu pravdepodobne sprevádzali aj fyzické či mentálne postihnutia. Možnou príčinou tejto polohy tak stále ostáva aj fyzická, či mentálna deformita jednotlivca, a tým jej odlišnost' a nedostatočná integrácia do spoločnosti. 
Za pozornost' tiež stojí, že v prípade jedincov pochovaných na pohrebiskách bolo v tejto polohe pochované len jedno diet’a, čo môže značit', že jedinec mohol byt' do tejto polohy daný ako následok za činy spáchané počas svojho života, ktorých sa dopustil ako plnoprávny, teda za seba nesúci zodpovednost' člen spoločnosti. V prípade jedincov z pohrebísk evokuje pochovanie v tejto polohe určitú formu trestu alebo následku určitého „činu“, prípadne to mohla byt' nedostatočná integrácia jedinca do spoločnosti, či už z dôvodov psychických, fyzických, alebo z dôvodu možného cudzieho pôvodu. Vzhl'adom na vysoký počet antropologicky neurčených jedincov však musíme mat' na zreteli, že tieto výsledky môžu byt' skreslené.

Ak k tomu prirátame fakt, že väčšina takto pochovaných jedincov z pohrebísk boli ženy, táto poloha nám naznačuje následok aktivít typických pre ženy či tradičnejšie spájaných so ženami. Ženy ovládajúce nižšiu, démonickú sféru kultu mohli byt' ako určitá forma kňažiek či vediem súčast'ou vtedajšej spoločnosti (Galuška 1996, 55). Ich existencia by určite nevyhovovala kňazom, ktorí sa snažili ako dominantné náboženstvo presadit' krest'anstvo. Ženy teda mohli byt' dávané do tejto polohy zámerne ako znak určitého potupenia, či práve ako spôsob pokánia za ich spôsob života. Prípadne im mal byt' takto zamedzený prístup do krest’anského záhrobia. Strach z ich „schopností“", ktorými museli oplývat’ už počas života, tiež mohol zohrat' svoju rolu a ciel’om opatrenia mohlo byt' spomínané zamedzenie návratu zo záhrobia.

U ostatných neštandardných hrobov môžeme skonštatovat', že sa v nich nachádza menej predmetov ako u regulárnych hrobov. Častejšie tiež evidujeme kombináciu viacerých anomálii $\mathrm{v}$ jednom hrobe, ked' jedinec bol uložený nielen v neregulárnej polohe, ale bol aj otočený opačne alebo priečne voči zaužívanej orientácii na pohrebisku. To nám však nenapovedá takmer nič o možných príčinách takéhoto pochovania. Preto, ako už bolo spomenuté, bude potrebné pozerat' na jednotlivé hroby z kontextu konkrétneho pohrebiska. Ako príklad sme si vybrali niektoré hroby nájdené na pohrebisku v Čakajovciach (Rejholcová 1995).

Zaujímavý je hrob 226 (Rejholcová 1995, 25), v ktorom bola uložená žena vo veku maturus, v orientácii juhovýchod-severozápad, teda opačne voči väčšine pochovaných. ${ }^{3}$ Hrob sa navyše nachádza na SV okraji pohrebiska. V hrobovom inventári boli okrem iného nájdené štyri zachované mozaikové koráliky. Očká na mozaikových korálikoch mohli mat' apotropaickú funkciu (Ungerman 2005, 725). Rovnako tzv. hadovitý závesok (podla Ungerman 2005, 730), resp. závesok typ Těmice (podl'a Chorvátová 2015, 164) naznačuje, že osoba mohla oplývat' určitými špeciálnymi schopnost’ami, ktoré určovali jej výnimočné miesto v spoločnosti a ktoré mohli ovplyvnit' aj jej vyhradené miesto na pochovanie. Tieto prívesky sú spájané so ženami, respektíve dievčatami, mesiacom a plodnost'ou. ${ }^{4}$ Lunica a s tým súvisiaci mesiac tiež môže mat' spojitost's výnimočnými schopnost’ami a vedomost’ami, mesačné bohyne boli zároveň pokladané aj za bohyne čarov a mágie (Chorvátová 1998a, 138), čo by mohlo signalizovat’ funkciu ženy z hrobu 226, ktorá mohla komunite slúžit' práve ako vedma.

Čakajovce sú v prípade orientácií východ-západ celkovo špecifický prípad, ked’že väčšina hrobových jám mala nadštandardnú vel'kost' a v niektorých sa dokonca nachádzala nadštandardná výbava (Rejholcová 1995, 8). V tomto prípade je teda možné premýšl'at' nad hypotézou, že títo jedinci tiež patrili k okrajovej skupine, ale k takej, ktorá sa nachádzala na „pozitívnom“ okraji spoločnosti. Aj bohato vybavený hrob muža (hrob 788, Rejholcová 1995, 88), považovaný za najstarší inhumačný na pohrebisku, bol orientovaný opačne. Mohli by sme preto uvažovat' nad tým, že v prípade tohto pohrebiska boli v opačnom smere ukladaní jedinci, ktorí v komunite zohrávali význačné či vedúce miesto. Paralelu by sme mohli hl'adat' v 17. storočí, kedy boli voči zaužívanému smeru pochovávania opačne orientovaní kňazi (Unger 2006, 110), ktorí mali byt' aj po smrti obrátení tvárou k svojim veriacim. Tak aj tieto osoby mali „viest’ svojich súkmeňovcov bezpečne do záhrobia“"

3 Výnimočnost' hrobu 226 si povšimla už H. Chorvátová (1998) vo svojej štúdii o amuletoch.

4 Významom luníc sa zaoberala podrobne vo svojom článku H. Chorvátová (1998a). 


\begin{tabular}{|c|c|c|c|c|c|c|c|c|c|c|c|c|c|c|c|c|c|}
\hline 莺 & 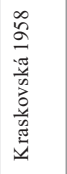 & 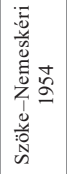 & 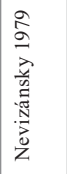 & 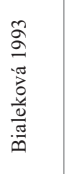 & 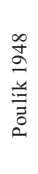 & 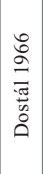 & 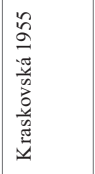 & 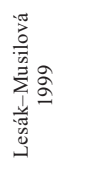 & 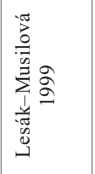 & $\begin{array}{l}\stackrel{\circ}{\circ} \\
\stackrel{\circ}{\pi} \\
\frac{\pi}{00} \\
\stackrel{0}{0}\end{array}$ & 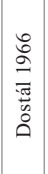 & 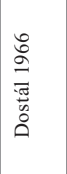 & 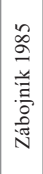 & 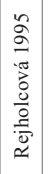 & 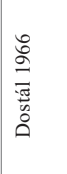 & 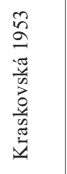 & 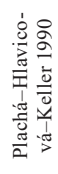 \\
\hline 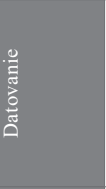 & 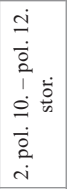 & 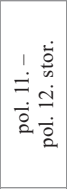 & 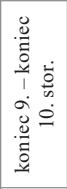 & 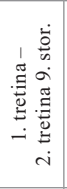 & 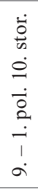 & 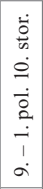 & 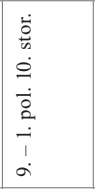 & 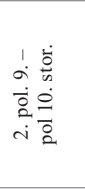 & $\begin{array}{l}\dot{0} \\
\dot{0} \\
1 \\
0 \\
0 \\
\dot{0} \\
\dot{0} \\
\dot{2} \\
\dot{2} \\
i\end{array}$ & $\begin{array}{l}\dot{\overrightarrow{0}} \\
\dot{0} \\
\stackrel{0}{0} \\
\overrightarrow{0} \\
\stackrel{0}{+} \\
1 \\
\dot{0}\end{array}$ & 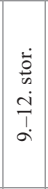 & $\begin{array}{l}\dot{0} \\
0 \\
0 \\
i \\
1 \\
a\end{array}$ & $\begin{array}{l}\dot{\overrightarrow{0}} \\
\dot{0} \\
\dot{0} \\
\stackrel{0}{0}\end{array}$ & $\begin{array}{c}\dot{0} \\
\vdots \\
0 \\
\dot{1} \\
1 \\
a \\
a\end{array}$ & $\begin{array}{l}\dot{0} \\
0 \\
0 \\
0 \\
1 \\
0 \\
0\end{array}$ & $\begin{array}{l}\dot{0} \\
0 \\
0 \\
\dot{a} \\
\dot{0} \\
\dot{\alpha} \\
\dot{i}\end{array}$ & 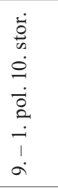 \\
\hline $\begin{array}{l}n \\
\text { in } \\
\text { in } \\
\text { क }\end{array}$ & 0 & 0 & 0 & 0 & 0 & - & 0 & - & 0 & 0 & - & - & - & $\infty$ & 0 & $\mathrm{~N}$ & $N$ \\
\hline $\begin{array}{l}N \quad \dot{\vec{y}} \\
> \\
>\end{array}$ & $N$ & $\simeq$ & 0 & $N$ & $N$ & 0 & 0 & $\sim$ & 0 & - & 0 & 0 & $N$ & $\stackrel{\infty}{\sim}$ & 0 & $a$ & สี \\
\hline 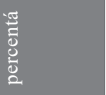 & $\stackrel{\circ}{\stackrel{2}{n}}$ & \begin{tabular}{l}
0 \\
\multirow{2}{*}{} \\
\multirow{6}{0}{} \\
0
\end{tabular} & & $\begin{array}{l}\dot{0}^{\circ} \\
\hat{\infty}^{2}\end{array}$ & $\begin{array}{l}\stackrel{0}{2} \\
\text { m } \\
\stackrel{+}{+}\end{array}$ & $\begin{array}{l}0 \\
0 \\
c \\
i n \\
i n\end{array}$ & & $\stackrel{\circ}{i n}$ & & $\begin{array}{l}\stackrel{0}{\circ} \\
\stackrel{8}{9}\end{array}$ & $\begin{array}{l}\stackrel{\circ}{\Xi} \\
=\end{array}$ & $\stackrel{\circ}{\stackrel{i}{े}}$ & $\begin{array}{c}0 \\
0 \\
i n \\
r\end{array}$ & $\begin{array}{l}\stackrel{0}{\circ} \\
\dot{f} \\
\dot{\sigma}\end{array}$ & & $\begin{array}{l}\text { å } \\
\text { a } \\
\text { i }\end{array}$ & $\begin{array}{l}\circ \\
\frac{2}{2} \\
2\end{array}$ \\
\hline 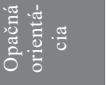 & $N$ & $\simeq$ & 0 & $N$ & $N$ & - & 0 & $m$ & 0 & - & - & - & $m$ & $\begin{array}{l}0 \\
n\end{array}$ & 0 & $=$ & $\stackrel{\sim}{\sim}$ \\
\hline 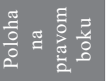 & N & 0 & $m$ & 0 & 0 & 0 & 0 & 0 & - & 0 & 0 & 0 & + & $n$ & - & 0 & 0 \\
\hline 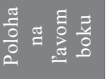 & - & - & 0 & - & 0 & - & - & - & 0 & 0 & 0 & 0 & - & m & 0 & 0 & in \\
\hline 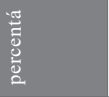 & $\begin{array}{l}\stackrel{\circ}{i} \\
\text { ì }\end{array}$ & & ì & 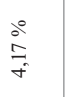 & & $\begin{array}{l}0 \\
0 \\
0 \\
i \\
i\end{array}$ & $\begin{array}{l}\stackrel{0}{0} \\
\dot{8} \\
\text { in }\end{array}$ & $\begin{array}{l}8 \\
8 \\
8 \\
i 1\end{array}$ & $\begin{array}{l}\stackrel{0}{0} \\
8 \\
i \\
i\end{array}$ & & & & $\begin{array}{l}\therefore \\
0 \\
0 \\
n \\
n\end{array}$ & $\begin{array}{l}0 \\
i \\
2 \\
0\end{array}$ & $\begin{array}{l}\stackrel{0}{0} \\
\stackrel{0}{\circ} \\
\stackrel{0}{0}\end{array}$ & & $\begin{array}{l}\stackrel{0}{2} \\
\stackrel{\infty}{\circ}\end{array}$ \\
\hline 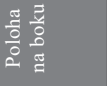 & $m$ & 0 & $m$ & - & 0 & - & - & - & - & 0 & 0 & 0 & in & 0 & - & 0 & $=$ \\
\hline 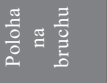 & o & 0 & 0 & 0 & 0 & 0 & 0 & 0 & 0 & 0 & 0 & 0 & 0 & 0 & 0 & 0 & m \\
\hline 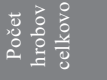 & $\vec{m}$ & $\Re$ & $\stackrel{ \pm}{=}$ & $\stackrel{\sim}{N}$ & fo & 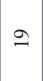 & ๐ે & r & $\sigma$ & - & $a$ & in & q & $\begin{array}{l}n \\
\infty \\
\infty\end{array}$ & - & i & 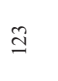 \\
\hline$\frac{\hat{\Xi}}{\frac{3}{0}}$ & 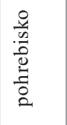 & 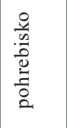 & 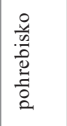 & 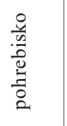 & 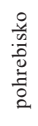 & 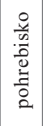 & 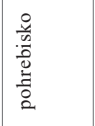 & 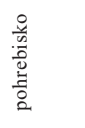 & 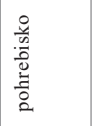 & 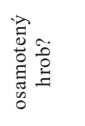 & 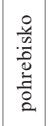 & 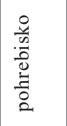 & 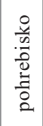 & 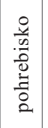 & 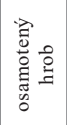 & 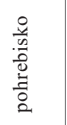 & 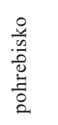 \\
\hline है & 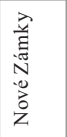 & 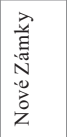 & 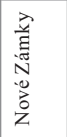 & 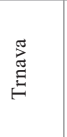 & 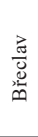 & 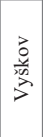 & 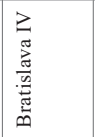 & 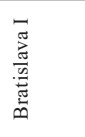 & 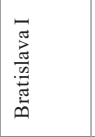 & 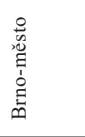 & $\begin{array}{l}\overrightarrow{3} \\
\text { 递 } \\
\text { s. } \\
\text { m. }\end{array}$ & 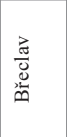 & 茎 & 尝 & $\mid \begin{array}{l}0 \\
\vdots \\
\vdots \\
0\end{array}$ & 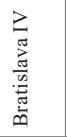 & 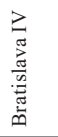 \\
\hline $\begin{array}{l}\frac{\pi}{0} \\
\frac{0}{0}\end{array}$ & $\begin{array}{l}\frac{7}{0} \\
\frac{0}{0} \\
\text { ㄹ. }\end{array}$ & 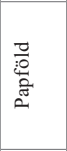 & 咅 & 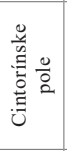 & 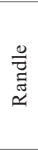 & 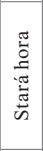 & 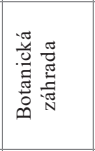 & 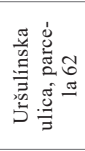 & 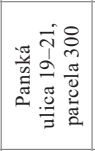 & 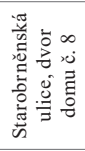 & 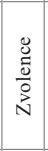 & 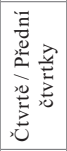 & 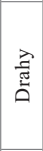 & 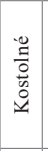 & 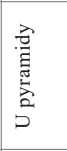 & 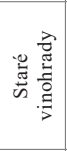 & $\begin{array}{l}\text { E } \\
\frac{0}{0} \\
\frac{0}{0} \\
0 \\
\frac{0}{\pi} \\
\text { N }\end{array}$ \\
\hline & 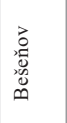 & 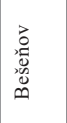 & 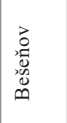 & 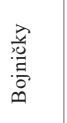 & 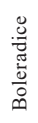 & 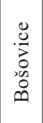 & 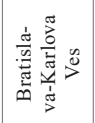 & 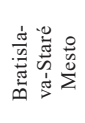 & 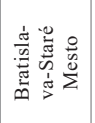 & 吕 & $\begin{array}{l}\vec{z} \\
\text { 递 } \\
\text { 总 }\end{array}$ & 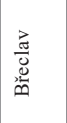 & 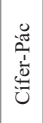 & 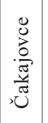 & 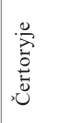 & 竞 & ڤี \\
\hline & - & $N$ & $m$ & $\nabla$ & in & 0 & r & $\infty$ & $a$ & 으 & $=$ & $\simeq$ & 9 & \pm & $\because$ & $\mathscr{0}$ & 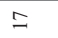 \\
\hline
\end{tabular}




\begin{tabular}{|c|c|c|c|c|c|c|c|c|c|c|c|c|c|c|c|c|c|c|}
\hline$\stackrel{\Xi}{g}$ & 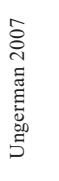 & 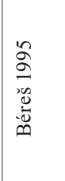 & 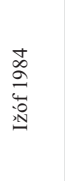 & 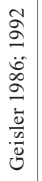 & 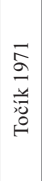 & 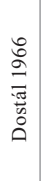 & 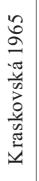 & 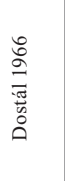 & 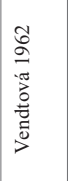 & 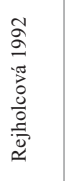 & 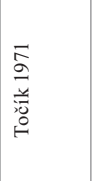 & 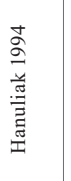 & 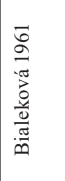 & 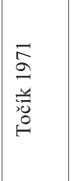 & 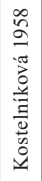 & 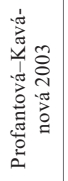 & 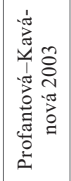 & 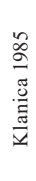 \\
\hline 气̊ & 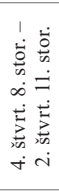 & 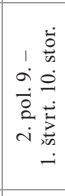 & $\begin{array}{l}\dot{0} \\
\vdots \\
\vdots \\
\sigma\end{array}$ & 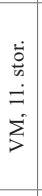 & $\begin{array}{c}\dot{0} \\
\dot{0} \\
\dot{0} \\
\stackrel{1}{1} \\
\dot{\sigma}\end{array}$ & 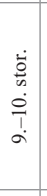 & 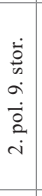 & $\begin{array}{l}\dot{0} \\
\frac{0}{0} \\
0 \\
0 \\
0\end{array}$ & $\mid \begin{array}{cc}1 & \dot{0} \\
0 & 0 \\
0 & 0 \\
0 & 0 \\
0 & 0 \\
i & 0 \\
N\end{array}$ & 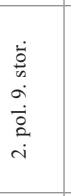 & $\begin{array}{l}\dot{0} \\
\vdots \\
0 \\
0 \\
\sigma \\
\sigma \\
\sigma\end{array}$ & 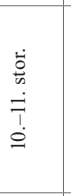 & 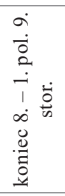 & 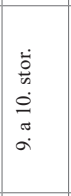 & $\begin{array}{c}\dot{0} \\
\dot{0} \\
\dot{0} \\
\dot{0} \\
\dot{0} \\
\vdots \\
\dot{1} \\
1 \\
\dot{a}\end{array}$ & 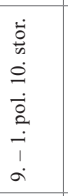 & 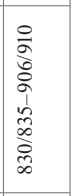 & $\begin{array}{c}\frac{1}{0} \\
0 \\
0 \\
0 \\
0 \\
0 \\
\stackrel{0}{1} \\
1 \\
0 \\
\end{array}$ \\
\hline is & $\tilde{\lambda}$ & 0 & N & - & 0 & $m$ & $N$ & 0 & 0 & - & a & 0 & - & N & 0 & 0 & in & in \\
\hline$>\pi$ & तิ & $m$ & N & $\vec{\lambda}$ & 0 & 0 & - & m & - & - & m & 0 & 0 & N & - & N & r & $\lambda$ \\
\hline 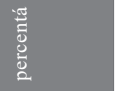 & $\begin{array}{l}\stackrel{\circ}{\grave{c}} \\
\stackrel{m}{m}\end{array}$ & $\begin{array}{l}\stackrel{0}{F} \\
\dot{F} \\
\dot{\sigma}\end{array}$ & iे & $\stackrel{\circ}{\varrho}$ & & $\begin{array}{l}0 \\
0 \\
0 \\
i \\
i\end{array}$ & 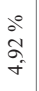 & $\stackrel{\circ}{m}$ & iे & $\begin{array}{l}\stackrel{0}{\circ} \\
\hat{6} \\
\stackrel{0}{0}\end{array}$ & $\begin{array}{l}\stackrel{0}{2} \\
\stackrel{2}{2} \\
\stackrel{2}{r}\end{array}$ & & $\stackrel{\circ}{\circ}$ & $\begin{array}{l}\stackrel{0}{ } \\
0 \\
0 \\
\text { In }\end{array}$ & $\begin{array}{l}\dot{0} \\
\vdots \\
i \\
n\end{array}$ & $\begin{array}{l}\stackrel{0}{\circ} \\
\stackrel{n}{i}\end{array}$ & $\begin{array}{l}\stackrel{0}{0} \\
\dot{m} \\
\dot{f}\end{array}$ & $\begin{array}{l}\stackrel{0}{2} \\
\infty \\
\stackrel{2}{=}\end{array}$ \\
\hline 鸷. & $q$ & $m$ & $\sigma$ & तี & 0 & $m$ & $m$ & $m$ & - & $\sim$ & in & 0 & - & + & - & N & $a$ & $\stackrel{\infty}{q}$ \\
\hline 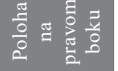 & $\stackrel{ \pm}{\sim}$ & - & 0 & - & $N$ & 0 & 0 & 0 & 0 & - & 0 & 0 & 0 & 0 & 0 & 0 & + & in \\
\hline 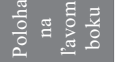 & $\grave{\imath}$ & 0 & 0 & $N$ & 0 & 0 & 0 & 0 & 0 & 0 & 0 & - & 0 & 0 & 0 & 0 & $m$ & - \\
\hline 总 & $\begin{array}{l}\stackrel{0}{0} \\
\infty \\
\infty \\
\infty\end{array}$ & 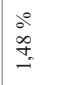 & & $\begin{array}{l}0 \\
0 \\
0 \\
- \\
- \\
-\end{array}$ & $\begin{array}{l}0 \\
0 \\
6 \\
i\end{array}$ & & & & & $\begin{array}{l}\stackrel{0}{0} \\
\hat{\infty} \\
\dot{0}\end{array}$ & & $\begin{array}{l}\stackrel{\circ}{0} \\
\text { ஸे }\end{array}$ & & & & & $\begin{array}{l}\circ \\
\dot{0} \\
i n \\
m\end{array}$ & $\begin{array}{l}\stackrel{0}{0} \\
\text { ì } \\
\text { in }\end{array}$ \\
\hline$\frac{0}{0} \frac{0}{0} \frac{0}{0}$ & $\bar{n}$ & - & 0 & $m$ & $N$ & 0 & 0 & 0 & 0 & - & 0 & - & 0 & 0 & 0 & 0 & r & 0 \\
\hline$\approx$ & - & 0 & 0 & 0 & 0 & - & o & 0 & 0 & 0 & 0 & - & 0 & 0 & 0 & 0 & 0 & N \\
\hline 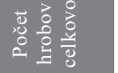 & $\stackrel{ }{\dddot{2}}$ & $\stackrel{\infty}{\infty}$ & $\varrho$ & స్ & $\approx$ & $\Xi$ & $\vec{\sigma}$ & 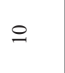 & ナ & $\simeq$ & $\stackrel{\infty}{\circ}$ & 孛 & - & $\approx$ & 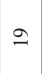 & I & §ి & $\stackrel{̊}{\text { i }}$ \\
\hline$\frac{⿱ \pi}{0}$ & 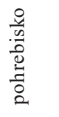 & 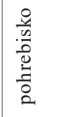 & 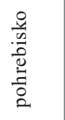 & 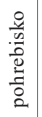 & 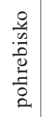 & 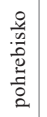 & 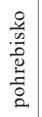 & 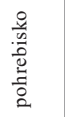 & 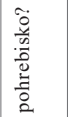 & 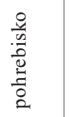 & 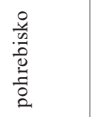 & 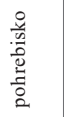 & 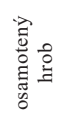 & 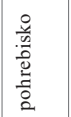 & 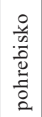 & 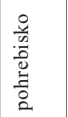 & 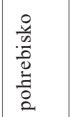 & 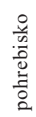 \\
\hline$\frac{5}{0}$ & 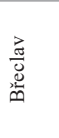 & 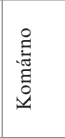 & 䄈 & 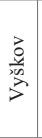 & 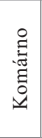 & 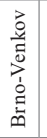 & 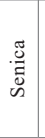 & 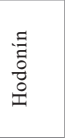 & $\stackrel{\Xi}{\stackrel{\Xi}{z}}$ & 茛 & 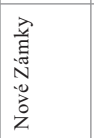 & 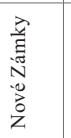 & 苟 & 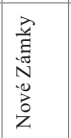 & $\begin{array}{l}\text { 慁 } \\
0 \\
0 \\
\\
\end{array}$ & 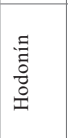 & 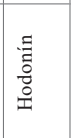 & 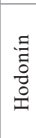 \\
\hline$\frac{\overline{0}}{0}$ & 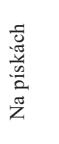 & 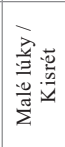 & 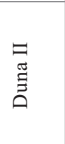 & 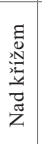 & & 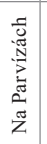 & 胥 & 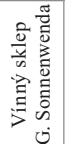 & & 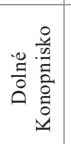 & 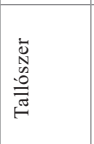 & 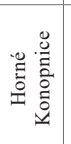 & & 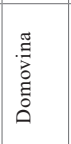 & 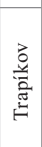 & 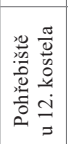 & 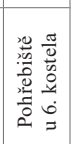 & 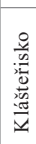 \\
\hline 戬 & 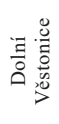 & 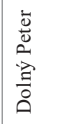 & 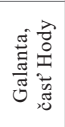 & 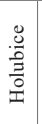 & 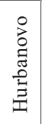 & 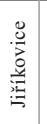 & 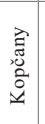 & $\stackrel{\overrightarrow{2}}{\sqrt[3]{y}}$ & $\mid$ & 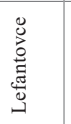 & 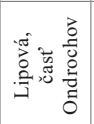 & 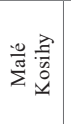 & 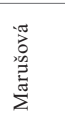 & 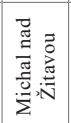 & 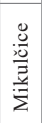 & 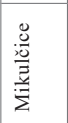 & 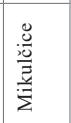 & $\begin{array}{l}\frac{8}{0} \\
\frac{000}{0} \\
\frac{3}{3} \\
\frac{3}{2}\end{array}$ \\
\hline & $\stackrel{\infty}{\underline{\infty}}$ & 2 & i & $\vec{N}$ & ה & $\tilde{\lambda}$ & $\stackrel{+}{\sim}$ & is & i & $\hat{\sim}$ & $\infty$ & ते & in & $\bar{m}$ & లె & $\hat{m}$ & 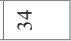 & 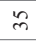 \\
\hline
\end{tabular}




\begin{tabular}{|c|c|c|c|c|c|c|c|c|c|c|c|c|c|c|c|c|}
\hline 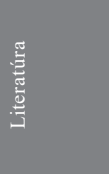 & 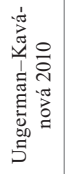 & 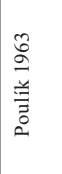 & 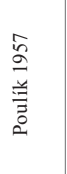 & 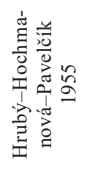 & 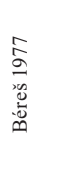 & 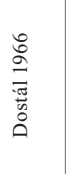 & 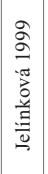 & 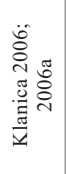 & 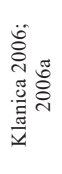 & 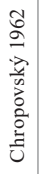 & 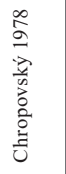 & 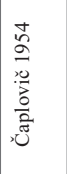 & 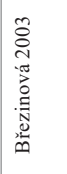 & 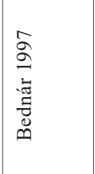 & 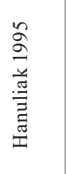 & 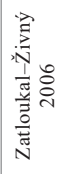 \\
\hline 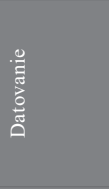 & $\begin{array}{l}\dot{0} \\
\dot{0} \\
i \\
i \\
1 \\
\dot{0} \\
\dot{0} \\
\dot{0} \\
\dot{0} \\
\dot{0} \\
\dot{0} \\
\dot{0} \\
\dot{0}\end{array}$ & $\begin{array}{l}\dot{0} \\
0 \\
0 \\
0 \\
\dot{0} \\
\dot{0} \\
\dot{T} \\
1 \\
0\end{array}$ & $\begin{array}{l}\dot{0} \\
0 \\
0 \\
0 \\
\dot{0} \\
\stackrel{0}{0} \\
\dot{T} \\
\dot{0}\end{array}$ & 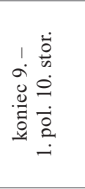 & $\begin{array}{l}\dot{0} \\
\dot{0} \\
\dot{0} \\
\dot{0} \\
\dot{a}\end{array}$ & 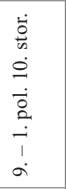 & 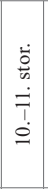 & $\begin{array}{l}\dot{0} \\
\frac{0}{0} \\
\dot{\overrightarrow{1}} \\
\dot{0}\end{array}$ & $\begin{array}{l}\dot{0} \\
\dot{0} \\
\dot{\vec{t}} \\
\stackrel{a}{a}\end{array}$ & $\begin{array}{l}\dot{\vec{s}} \\
\stackrel{0}{0} \\
a\end{array}$ & $\begin{array}{l}\dot{b} \\
\dot{0} \\
0 \\
0 \\
1 \\
0\end{array}$ & 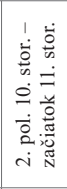 & $\begin{array}{l}\ddot{5} \\
\vdots \\
0 \\
a\end{array}$ & $\begin{array}{l}4 \\
0 \\
0 \\
0 \\
0 \\
1 \\
0 \\
\dot{0} \\
\dot{0} \\
2 \\
\dot{i}\end{array}$ & 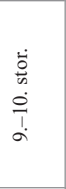 & 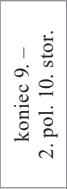 \\
\hline $\begin{array}{l}n \\
\vec{i} \\
\vec{i} \\
\sim\end{array}$ & ల్ల & - & + & 0 & 0 & 0 & - & 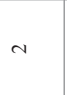 & $r$ & - & in & 0 & 0 & $m$ & - & 0 \\
\hline $\begin{array}{l}N \frac{1}{0} \\
> \\
>\end{array}$ & లి & 0 & 0 & - & - & - & $N$ & 0 & $a$ & $m$ & + & - & 0 & 0 & 0 & - \\
\hline 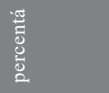 & $\begin{array}{l}\stackrel{0}{2} \\
\vec{n} \\
\stackrel{0}{\circ}\end{array}$ & $\begin{array}{l}\text { o̊ } \\
\text { in } \\
0\end{array}$ & $\begin{array}{l}\text { वे } \\
\text { d } \\
\text { i }\end{array}$ & $\begin{array}{l}0 \\
\infty \\
i \\
i\end{array}$ & $\begin{array}{l}\circ \\
i n\end{array}$ & $\stackrel{\circ}{=}$ & $\begin{array}{l}\therefore \\
i \\
=\end{array}$ & $\begin{array}{l}\stackrel{0}{\circ} \\
\stackrel{2}{1}\end{array}$ & $\begin{array}{l}\stackrel{0}{\infty} \\
\stackrel{\infty}{n}\end{array}$ & $\begin{array}{l}\stackrel{0}{2} \\
n \\
m \\
\overbrace{}^{2}\end{array}$ & $\begin{array}{l}\circ \\
\frac{0}{2} \\
=\end{array}$ & $\begin{array}{l}0 \\
0 \\
0 \\
0 \\
0\end{array}$ & $\frac{2}{2}$ & $\begin{array}{l}\circ \\
\stackrel{0}{0}\end{array}$ & $\begin{array}{l}\circ \\
\vdots \\
0 \\
0 \\
0\end{array}$ & $\begin{array}{l}\dot{0} \\
i \\
i \\
+\end{array}$ \\
\hline 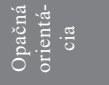 & 8 & - & $\nabla$ & - & - & - & $m$ & $\infty$ & $\stackrel{0}{-}$ & $\nabla$ & $a$ & - & 0 & $m$ & - & - \\
\hline 吾 & 0 & 0 & - & 0 & 0 & 0 & $N$ & 0 & $N$ & $N$ & + & - & 0 & 0 & - & 0 \\
\hline $\begin{array}{l}\frac{\pi}{0} \\
\frac{0}{0} \\
\stackrel{0}{\circ}\end{array}$ & in & 0 & 0 & 0 & 0 & 0 & $N$ & 0 & 0 & - & 0 & 0 & 0 & 0 & 0 & 0 \\
\hline $\begin{array}{l}\text { हैँ } \\
\text { हूँ } \\
\text { ह. }\end{array}$ & $\begin{array}{l}\stackrel{0}{0} \\
\infty \\
\infty \\
0\end{array}$ & & $\begin{array}{l}0 \\
\frac{0}{n} \\
0\end{array}$ & & & & $\begin{array}{l}\therefore \\
\hat{n} \\
-i\end{array}$ & & $\begin{array}{l}\stackrel{0}{2} \\
i \\
i\end{array}$ & $\begin{array}{l}0 \\
0 \\
\text { iे } \\
\text { ri }\end{array}$ & $\begin{array}{l}\therefore \\
\dot{0} \\
i\end{array}$ & $\begin{array}{l}0 \\
8 \\
0 \\
0\end{array}$ & & & $\begin{array}{l}\circ \\
\vdots \\
0 \\
0\end{array}$ & \\
\hline 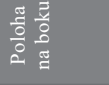 & in & 0 & - & 0 & 0 & 0 & $\sigma$ & 0 & $N$ & $m$ & 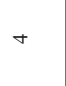 & - & 0 & 0 & - & 0 \\
\hline 융 퓽 률 & 0 & 0 & 0 & - & 0 & 0 & 0 & 0 & 0 & 0 & - & 0 & 0 & 0 & 0 & 0 \\
\hline 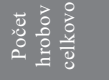 & $\vec{n}$ & $\stackrel{2}{0}$ & $\stackrel{2}{\circ}$ & i & $N$ & $a$ & $\vec{\sim}$ & గె & $\infty$ & $\alpha$ & $\approx$ & 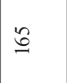 & $r$ & $m$ & 0 & $\vec{\sim}$ \\
\hline$\frac{\frac{\pi}{\pi}}{\frac{\pi}{0}}$ & 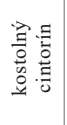 & 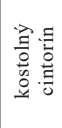 & 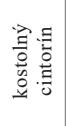 & 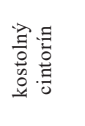 & $\begin{array}{l}\circ \\
\frac{8}{0} \\
0 \\
0 \\
0 \\
\vdots \\
0\end{array}$ & 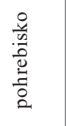 & 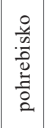 & 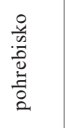 & 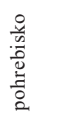 & 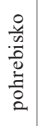 & 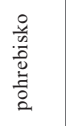 & 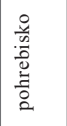 & 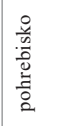 & 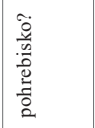 & 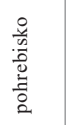 & 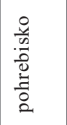 \\
\hline$\stackrel{5}{c}$ & 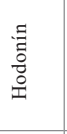 & 吾 & $\begin{array}{l}\frac{\Xi}{3} \\
\frac{0}{0} \\
0\end{array}$ & 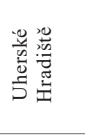 & 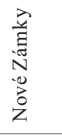 & 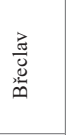 & 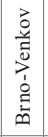 & 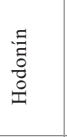 & $\begin{array}{l}\Xi \\
\vdots \\
0 \\
0 \\
0\end{array}$ & $\stackrel{\mathbb{E}}{\stackrel{\Xi}{Z}}$ & $\stackrel{\Xi}{\frac{\tilde{z}}{z}}$ & 节 & 苦 & $\stackrel{\Xi}{\Xi}$ & $\stackrel{\Xi}{\stackrel{\Xi}{Z}}$ & \\
\hline $\bar{c}$ & 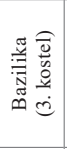 & 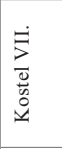 & 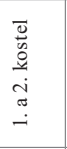 & 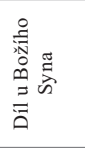 & 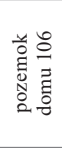 & 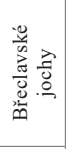 & & 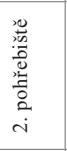 & 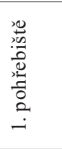 & 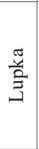 & 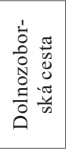 & & 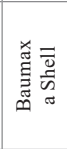 & 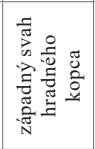 & 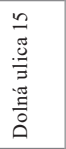 & 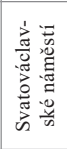 \\
\hline$\frac{5}{5}$ & 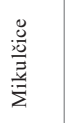 & 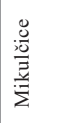 & 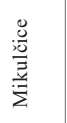 & 焉 & 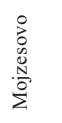 & 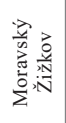 & 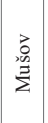 & 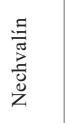 & 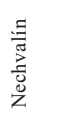 & 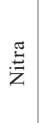 & $\stackrel{\Xi}{\frac{\pi}{z}}$ & 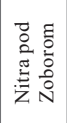 & 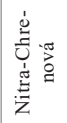 & 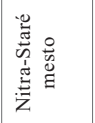 & 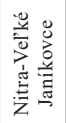 & $\begin{array}{c}0 \\
0 \\
0 \\
0 \\
0\end{array}$ \\
\hline & in & $n$ & $\infty$ & ले & P & $\vec{F}$ & ร & $q$ & 拐 & ? & fo & f & $\stackrel{\infty}{+}$ & g & in & $\vec{n}$ \\
\hline
\end{tabular}




\begin{tabular}{|c|c|c|c|c|c|c|c|c|c|c|c|c|c|c|c|c|c|c|}
\hline 苞 & 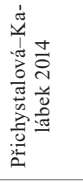 & 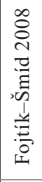 & 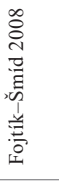 & 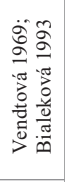 & 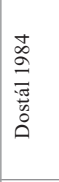 & 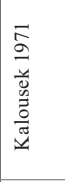 & 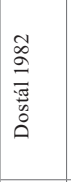 & 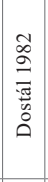 & 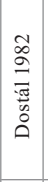 & 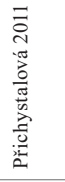 & 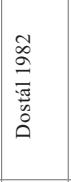 & 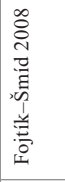 & 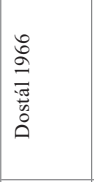 & 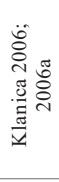 & 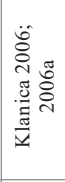 & 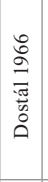 & 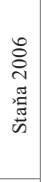 & 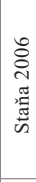 \\
\hline 递 & 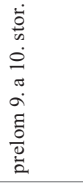 & $\sum$ & $\begin{array}{l}\dot{0} \\
\dot{0} \\
0 \\
0 \\
- \\
\dot{0} \\
\vdots \\
\dot{1} \\
\vdots \\
0\end{array}$ & 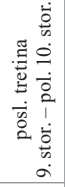 & 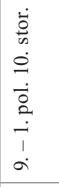 & 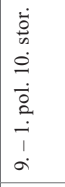 & $\begin{array}{c}\dot{1} \\
\stackrel{0}{0} \\
0 \\
\vdots \\
\dot{0} \\
\dot{0} \\
\vdots \\
1 \\
1 \\
0 \\
\end{array}$ & 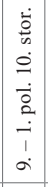 & 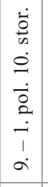 & 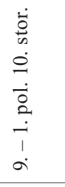 & 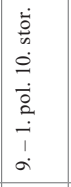 & 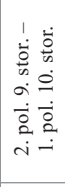 & 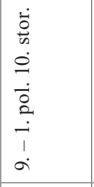 & 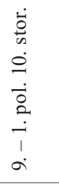 & 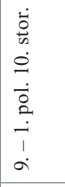 & 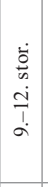 & $\begin{array}{c}\dot{\vec{g}} \\
w \\
\dot{0} \\
\dot{0} \\
\dot{0} \\
\stackrel{0}{1} \\
\dot{-} \\
\dot{\sigma}\end{array}$ & $\begin{array}{c}\dot{0} \\
0 \\
0 \\
0 \\
\dot{0} \\
\stackrel{0}{0} \\
\stackrel{1}{1} \\
\vdots \\
0\end{array}$ \\
\hline $\begin{array}{l}0 \\
i \\
i s \\
\text { is }\end{array}$ & - & 0 & - & $\infty$ & - & 0 & 0 & - & - & in & $a$ & - & N & $\sim$ & $\vec{\sim}$ & 0 & \pm & - \\
\hline & 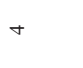 & - & 0 & $\simeq$ & 0 & 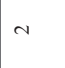 & 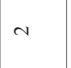 & N & $N$ & 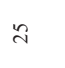 & 0 & $m$ & 0 & $\infty$ & \pm & - & $a$ & \pm \\
\hline 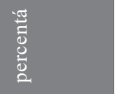 & ळे & $\stackrel{\circ}{\varrho}$ & $\stackrel{\circ}{\varrho}$ & $\begin{array}{l}\stackrel{n}{\simeq} \\
\cong\end{array}$ & $\begin{array}{l}\therefore \\
\dot{0} \\
\alpha\end{array}$ & $\begin{array}{l}\stackrel{0}{0} \\
\dot{q} \\
0 \\
0\end{array}$ & $\begin{array}{l}\text { à } \\
\text { iे } \\
\text { b }\end{array}$ & 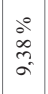 & $\begin{array}{l}\dot{0} \\
\vec{q} \\
\vec{N}\end{array}$ & $\begin{array}{l}\stackrel{0}{2} \\
\stackrel{i}{ \pm}\end{array}$ & $\stackrel{\circ}{+}$ & 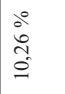 & 离 & $\begin{array}{l}\stackrel{0}{2} \\
\stackrel{i}{i} \\
i\end{array}$ & $\begin{array}{l}\stackrel{0}{0} \\
\stackrel{1}{=}\end{array}$ & $\begin{array}{l}\text { o } \\
\text { iे }\end{array}$ & $\begin{array}{l}\stackrel{0}{2} \\
\stackrel{n}{N}\end{array}$ & 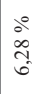 \\
\hline & in & - & - & ते & - & 4 & 4 & m & $m$ & in & $a$ & t & N & 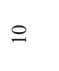 & $\approx$ & - & $\tilde{\sim}$ & $\stackrel{n}{\prime}$ \\
\hline 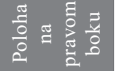 & - & 0 & $\circ$ & $\sim$ & 0 & 0 & - & - & 0 & r & - & 0 & 0 & $\sim$ & in & 0 & $\simeq$ & 0 \\
\hline$\approx$ & 。 & 0 & 0 & - & 0 & 0 & - & 0 & $N$ & $a$ & - & 0 & 0 & 0 & $\infty$ & 0 & $=$ & 0 \\
\hline 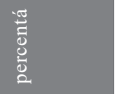 & $\therefore$ & & & & & & $\begin{array}{l}\therefore 0 \\
i n \\
\text { î }\end{array}$ & $\begin{array}{l}\therefore \\
\stackrel{2}{m} \\
m\end{array}$ & $\begin{array}{l}\dot{\circ} \\
\grave{T} \\
\dot{I}\end{array}$ & $\begin{array}{l}\stackrel{\circ}{2} \\
\hat{n} \\
r\end{array}$ & $\begin{array}{l}\therefore \\
\stackrel{0}{8} \\
\stackrel{+}{+}\end{array}$ & & & $\begin{array}{l}a^{0} \\
\hat{n} \\
0 \\
0\end{array}$ & $\begin{array}{l}\stackrel{0}{ } \\
\stackrel{2}{f} \\
\stackrel{f}{*}\end{array}$ & & $\begin{array}{l}\stackrel{0}{0} \\
\stackrel{n}{n}\end{array}$ & \\
\hline 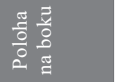 & - & 0 & 0 & $m$ & 0 & 0 & N & - & $\sim$ & 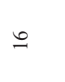 & 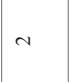 & 0 & 0 & $N$ & $\cong$ & 0 & $\tilde{\sim}$ & 0 \\
\hline 5 & 4 & 0 & 0 & - & $N$ & 0 & 0 & 0 & 0 & - & 0 & 0 & 0 & - & m & 0 & $a$ & 0 \\
\hline$\therefore$ 올 흘 & $\stackrel{\circ}{\circ}$ & $\cong$ & - & $\widetilde{\sigma}$ & $=$ & ò & లె & $\approx$ & \pm & $\stackrel{\sim}{\sim}$ & in & mे & $\infty$ & $\hat{\mathrm{D}}$ & $\frac{m}{m}$ & + & हे & નे \\
\hline$\frac{\circ}{0}$ & 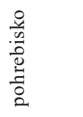 & 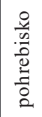 & 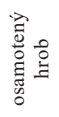 & 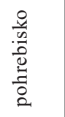 & 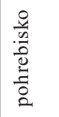 & 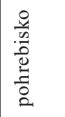 & 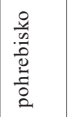 & 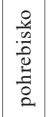 & 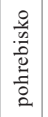 & 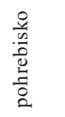 & 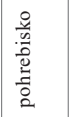 & 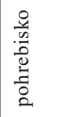 & 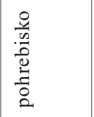 & 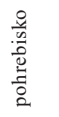 & 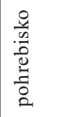 & 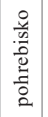 & 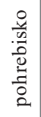 & 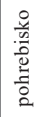 \\
\hline$\frac{\text { s. }}{0}$ & $\begin{array}{l}\frac{.}{0} \\
\vdots \\
0 \\
0\end{array}$ & 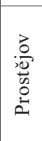 & 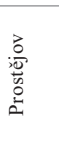 & 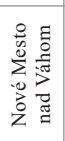 & 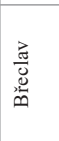 & 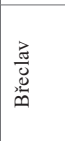 & 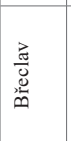 & 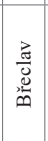 & 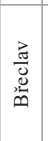 & 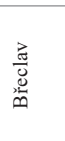 & 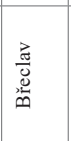 & 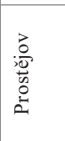 & 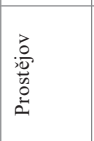 & 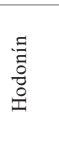 & \begin{tabular}{|l} 
慁 \\
总 \\
垔
\end{tabular} & 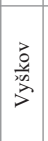 & 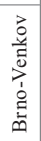 & 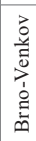 \\
\hline$\frac{\text { 용 }}{0}$ & 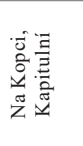 & 莒 & 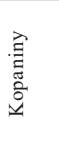 & 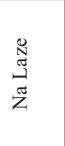 & 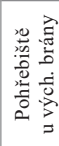 & 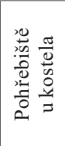 & 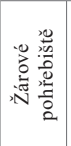 & 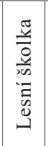 & 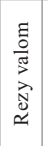 & 宽 & 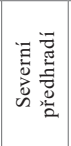 & 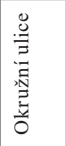 & 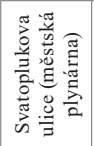 & 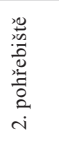 & 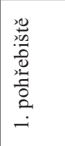 & 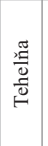 & 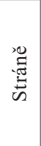 & 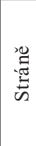 \\
\hline 亲 & 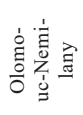 & 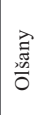 & 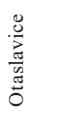 & 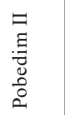 & 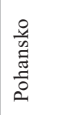 & 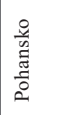 & 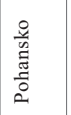 & 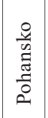 & 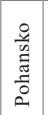 & 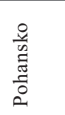 & 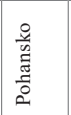 & 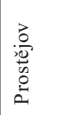 & 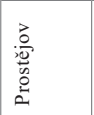 & 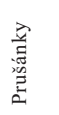 & 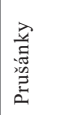 & 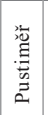 & 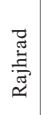 & 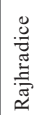 \\
\hline & $\therefore$ & in & in & in & in & in & in & in & 8 & $\bar{\sigma}$ & $\mathcal{\sigma}$ & 8 & I & $\ddot{8}$ & 8 & 5 & $\infty$ & 8 \\
\hline
\end{tabular}




\begin{tabular}{|c|c|c|c|c|c|c|c|c|c|c|c|c|c|c|c|c|}
\hline 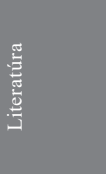 & 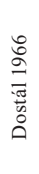 & 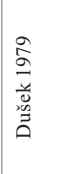 & 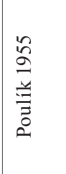 & 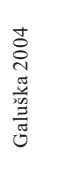 & 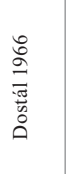 & 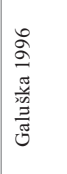 & 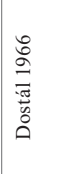 & 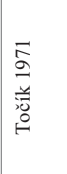 & 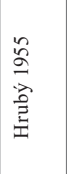 & 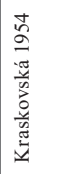 & 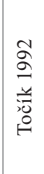 & 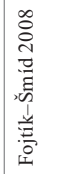 & 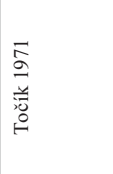 & 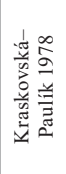 & $\begin{array}{l}\stackrel{8}{\circ} \\
\stackrel{0}{0} \\
\frac{\pi}{50} \\
\stackrel{0}{0}\end{array}$ & 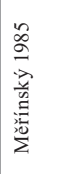 \\
\hline 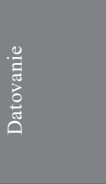 & $\begin{array}{l}\dot{0} \\
0 \\
0 \\
0 \\
\dot{0} \\
\dot{0} \\
\stackrel{0}{0} \\
1 \\
\dot{0}\end{array}$ & 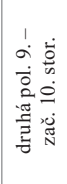 & $\begin{array}{c}\dot{1} \\
0 \\
0 \\
0 \\
0 \\
\dot{0} \\
\vdots \\
\vdots \\
\dot{i} \\
1 \\
0\end{array}$ & $\begin{array}{l}\dot{0} \\
0 \\
0 \\
\dot{0} \\
\dot{0} \\
0\end{array}$ & $\begin{array}{c}\dot{1} \\
0 \\
0 \\
0 \\
0 \\
\dot{0} \\
\vdots \\
\vdots \\
\dot{-} \\
1 \\
0\end{array}$ & 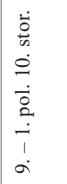 & 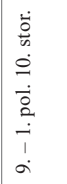 & $\begin{array}{l}0 \\
0 \\
0 \\
1 \\
0 \\
2 \\
n\end{array}$ & 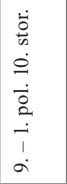 & $\begin{array}{l}\dot{0} \\
0 \\
0 \\
0\end{array}$ & 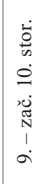 & 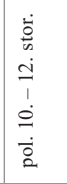 & 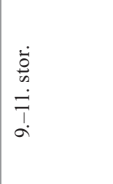 & $\begin{array}{c}\dot{0} \\
\vdots \\
0 \\
\vdots \\
\dot{0} \\
\dot{0} \\
\dot{i}\end{array}$ & $\begin{array}{l}\dot{0} \\
\dot{0} \\
\dot{0} \\
\dot{0} \\
\dot{0} \\
\vdots \\
\vdots \\
\vdots \\
\dot{0}\end{array}$ & 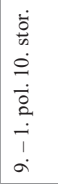 \\
\hline 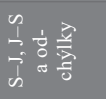 & - & 0 & - & 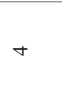 & t & 0 & 0 & 0 & ले & 0 & 0 & 0 & $N$ & 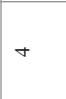 & 0 & N \\
\hline $\begin{array}{l}N+\frac{\lambda}{2} \\
>\end{array}$ & $\mathrm{N}$ & - & 0 & 0 & - & N & n & 0 & 守 & $m$ & $\sim$ & - & $\tilde{\lambda}$ & - & - & - \\
\hline 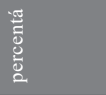 & $\begin{array}{l}\therefore \\
8 \\
\therefore \\
i n\end{array}$ & $\begin{array}{l}0 \\
\hat{m} \\
i \\
\text { i }\end{array}$ & $\begin{array}{c}\stackrel{0}{2} \\
m \\
i \\
i\end{array}$ & $\begin{array}{l}\therefore \\
8 \\
0 \\
0 \\
i\end{array}$ & $\begin{array}{l}\circ \\
\hat{B} \\
=\end{array}$ & $\begin{array}{l}\dot{0} \\
\dot{0} \\
i \\
i\end{array}$ & ஓं & 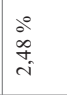 & $\begin{array}{l}\stackrel{0}{2} \\
\stackrel{y}{1} \\
\text { in }\end{array}$ & $\stackrel{\circ}{8}$ & $\begin{array}{l}\stackrel{0}{0} \\
\stackrel{0}{\infty} \\
\infty\end{array}$ & $\begin{array}{l}\text { in } \\
\text { in }\end{array}$ & $\begin{array}{l}\stackrel{0}{2} \\
i n \\
\dot{\gamma}\end{array}$ & $\begin{array}{l}\therefore \\
\infty \\
\infty \\
\stackrel{i}{1}\end{array}$ & $\begin{array}{l}\stackrel{0}{\stackrel{0}{\sigma}} \\
\stackrel{+}{*}\end{array}$ & $\begin{array}{l}\stackrel{0}{\stackrel{0}{=}} \\
\dot{f}\end{array}$ \\
\hline 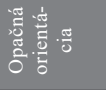 & $m$ & - & - & $\nabla$ & in & $N$ & $m$ & 0 & $\stackrel{\infty}{\sim}$ & $m$ & $\sim$ & - & ন & in & - & $m$ \\
\hline 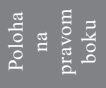 & 0 & 0 & 0 & - & 0 & 0 & 0 & + & - & 0 & 0 & - & 0 & 0 & 0 & 0 \\
\hline 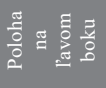 & 0 & 0 & 0 & 0 & 0 & 0 & 0 & $N$ & n & 0 & - & 0 & m & - & 0 & 0 \\
\hline 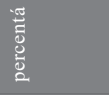 & & & & $\begin{array}{l}0_{0}^{\circ} \\
6 \\
0 \\
0\end{array}$ & & & & $\begin{array}{l}0 \\
\stackrel{0}{\infty} \\
\stackrel{\infty}{+} \\
i\end{array}$ & $\begin{array}{c}\stackrel{0}{0} \\
\text { ì } \\
0\end{array}$ & & \begin{tabular}{l}
20 \\
2 \\
2 \\
\multirow{2}{*}{}
\end{tabular} & $\begin{array}{l}0 \\
8 \\
8 \\
i j \\
i j\end{array}$ & $\stackrel{\circ}{\circ}$ & $\stackrel{\therefore}{\stackrel{0}{+}}$ & & \\
\hline 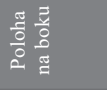 & 0 & 0 & 0 & - & 0 & 0 & 0 & 0 & t & 0 & - & - & 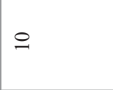 & - & 0 & 0 \\
\hline$\frac{\dddot{g}}{\circ} \cong \frac{}{0}$ & 0 & 0 & 0 & 0 & 0 & 0 & 0 & - & 0 & 0 & 0 & 0 & N & 8 & 0 & - \\
\hline 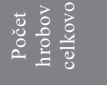 & 0 & F & F & 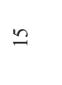 & $\mathscr{F}$ & $\infty$ & in & ป & 竎 & in & $\ddot{\sim}$ & $\nabla$ & $\stackrel{\infty}{\sim}$ & $\stackrel{d}{N}$ & $\stackrel{\sim}{N}$ & $\mathbb{N}$ \\
\hline 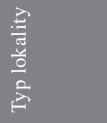 & 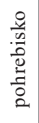 & 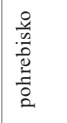 & 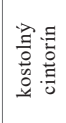 & 总 & 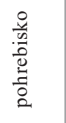 & 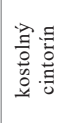 & 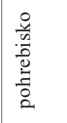 & 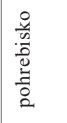 & 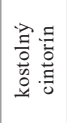 & 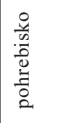 & 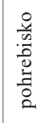 & 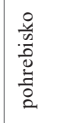 & 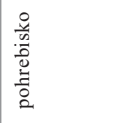 & 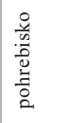 & 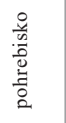 & 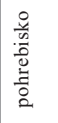 \\
\hline$\frac{\text { है }}{0}$ & 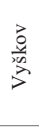 & 㺃 & 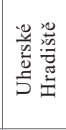 & 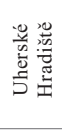 & 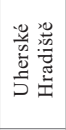 & 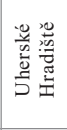 & 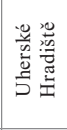 & 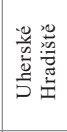 & 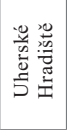 & $\frac{\overrightarrow{3}}{0}$ & 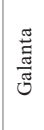 & 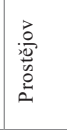 & 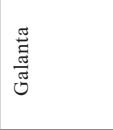 & 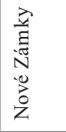 & 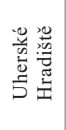 & 疍 \\
\hline$\stackrel{\circ}{\complement}$ & 䍃 & 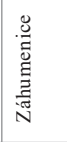 & 竎 & 总 & 章 & $\overrightarrow{\vec{E}}$ & 忞 & 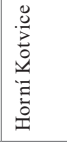 & $\begin{array}{l}\frac{5}{0} \\
\frac{0}{\pi} \\
\frac{\pi}{3} \\
\pi \\
z\end{array}$ & 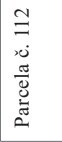 & 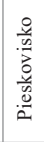 & 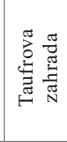 & 芯 & 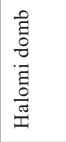 & $\begin{array}{l}\vec{y} \\
\frac{\vec{b}}{0} \\
\overrightarrow{3}\end{array}$ & $\frac{2}{\frac{2}{2}}$ \\
\hline$\frac{ \pm}{5}$ & $\begin{array}{l}\vec{z} \\
\stackrel{\Xi}{0} \\
0 \\
0 \\
\simeq\end{array}$ & 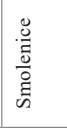 & 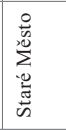 & 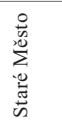 & 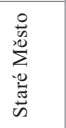 & 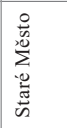 & 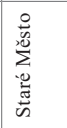 & 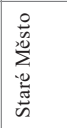 & 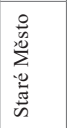 & 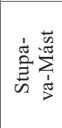 & 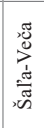 & 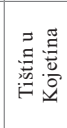 & 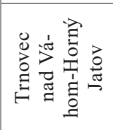 & $\begin{array}{l}0 \\
0 \\
0 \\
0 \\
0 \\
00 \\
0 \\
0 \\
1 \\
1 \\
1\end{array}$ & 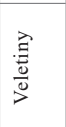 & $\frac{0}{\frac{8}{3}} \frac{0}{\frac{0}{9}}$ \\
\hline & 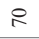 & $F$ & $\pi$ & $\cong$ & 咅 & 2 & 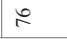 & $\approx$ & $\stackrel{\infty}{\sim}$ & 2 & $\triangleright$ & $\bar{\infty}$ & $\infty$ & $\infty$ & $\underset{\infty}{+}$ & $\infty$ \\
\hline
\end{tabular}




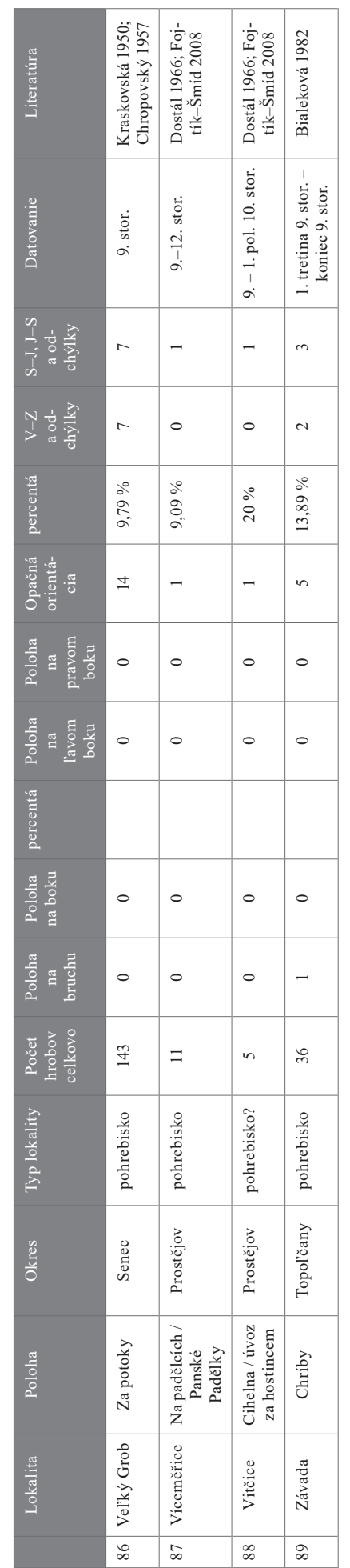

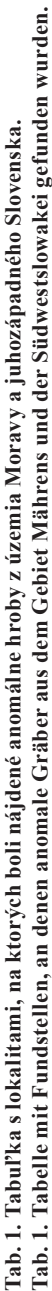

\section{Záver}

Anomálne hroby vzbudzujú pozornost' už dlhé desat'ročia a záujem o ne stále neopadá. Je t'ažké z dostupných informácií zistit', aké dôvody viedli pozostalých $\mathrm{k}$ pochovaniu mŕtvych v odlišnej polohe a ako týchto jednotlivcov vnímali. Aj ked'v stredoeurópskom priestore je viac zdôrazňovaná záporná interpretácia týchto polôh, a teda pôvod týchto jedincov býva dávaný na negatívny okraj spoločnosti, v ktorom sú zaradení rôzni vyvrheli, postihnutí, neintegrovaní jedinci či jedinci, ktorí mohli vyvolávat' strach, či už za života alebo po smrti, treba mat' na pamäti, že môže íst' aj o jedincov, ktorí boli výnimoční v pozitívnom slova zmysle. Vel'kost' ich hrobovej jamy, prípadne aj jej konštrukcia, či výbava naznačujú, že jedinec mohol svojím postavením ovplyvňovat’ život komunity aj kladným spôsobom. Zároveň treba mat' na zreteli, že jednotlivé interpretácie sa môžu líšit' a pri týchto hroboch sa tažko hladajú zovšeobecňujúce pravidlá, ktoré by sme mohli jednoducho aplikovat' na konkrétny hrob, pretože ani tieto hroby nie sú úplne rovnaké. Pri skúmaní hrobov a pohrebných zvykov musíme brat' do úvahy, že pri obmedzeným možnostiach, ktoré nám poskytujú dostupné pramene, budú naše poznatky stále len vel'mi vágnym náčrtom možných skutočných udalostí.

Štúdia bola vypracovaná v rámci projektu 2/0044/14 agentúry VEGA: Materiálna kultúra a jej prínos k rekonštrukcii pozemského života a pohrebných zvykov v stredovekej societe.

\section{Literatúra}

ASPÖCK, E., 2008: What Actually is a "Deviant Burial"? Comparing German-Language and Anglophone Research on "Deviant Burials". In: Deviant burial in the archaeological record (Murphy, E. M., ed.), 17-34. Oxford.

BEDNÁR, P., 1997: Výskum západného opevnenia hradného kopca v Nitre. In: AVANS 1995, 29-30. Nitra.

BIALEKOVÁ, D., 1961: Slovanský nález z Marušovej, ŠZ AÚ SAV 6, 283.

- 1982: Slovanské pohrebisko v Závade - Slawisches Gräberfeld in Závada, SlArch XXX, 123-164. 
- 1993: Slovanské pohrebisko v Bojničkách - Slawisches Gräberfeld in Bojničky, ŠZ AÚ SAV 29, 223-258.

DOSTÁL, B., 1966: Slovanská pohřebiště ze střední doby hradištní na Moravě. Praha.

- 1982: Drobná pohřebiště a rozptýlené hroby z Břeclavi-Pohanska - Kleine Gräberfelder und zerstreute Gräber von Břeclav-Pohansko, SPFFBU E 27, 135-198.

- 1984: Východní brána hradiska Pohanska - Das Osttor des Burgwalls Pohansko, SPFFBU E 29, 143-166.

FOJTÍK, P.-ŠMÍD, M., 2008: Slovanské hroby a pohřebiště na Prostějovsku - Slawische Gräber und Gräberfelder in der Region von Prostějov, Pravěk - Supplementum 18. Brno.

GALUŠKA, L., 1996: Slované. Doteky předků. Brno.

- 2004: Velkomoravské hroby revenantů ze Starého města. In: Zborník na počest' Dariny Bialekovej (Fusek, G., ed.), 81-90. Nitra.

GARDEŁA, L., 2011: Gryź ziemię! Pochówki na brzuchu we wczesnośredniowiecznej Polsce w perspektywie porównawczej - Frühmittelalterliche Bestattungen in Bauchlage in Polen im Vergleich, Pomniki Dawnego Prawa 16, 38-59.

- 2012: Pochówki na brzuchu we wczesnośredniowiecznej Polsce - Frühmittelalterliche Bestattungen in Bauchlage in Polen im Vergleich, Pomniki Dawnego Prawa - Suplementum 20, 30-37.

GEISLER, M., 1986: Holubice. Pohřebiště z mladohradištního období. Brno.

- 1992: Statistické zhodnocení mladohradištního pohřebiště z Holubic, okr. Vyškov - Statistische Bewertung des jungburgwallzeitlichen Gräberfeldes aus Holubice, Bez. Vyškov, Pravěk NŘ 2, 359-370.

HANÁKOVÁ, H.-STAŇA, Č.-STLOUKAL, M., 1986: Velkomoravské pohřebiště v Rajhradě Das grossmährische Gräberfeld in Rajhrad. Praha.

HANULIAK, M., 1994: Zvláštnosti v pohrebnom ríte ako súčast' duchovnej kultúry v 9.-10. storočí - Besonderheiten im Grabritus als Bestandteile der geisten Kultur im 9.-10. Jahrhundert, AH 19, 391-403.

- 1995: Vel'komoravské pohrebisko z Nitry-Vel'kých Janíkoviec. In: AVANS 1993, 50. Nitra.

- 2004: Charakter a význam hraníc v časopriestorovej dimenzii pohrebného rítu z mladšieho úseku včasného stredoveku - Charakter und Bedeutung der Grenzen in der zeiträumlichen Dimension des Begräbnisritus im jüngeren Abschnitt Frühmittelalters, AH 29, 37-51.

- 2004a: Vel'komoravské pohrebiská. Pochovávanie v 9.-10. storočí na území Slovenska - Großmährische Gräberfelder. Bestattung im 9.-10. Jahrhundert auf dem Gebiet der Slowakei. Nitra.

HORÁČKOVÁ, L.-VARGOVÁ, L.-STROUHAL, E., 2004: Základy paleopatologie. Brno.

HOŠŠO, J., 1975: Kostolné cintoríny v Liptovskej Mare a Liptovskej Sielnici (výsledky historickoarcheologického výskumu), Liptov 3, 121-166.

HRUBÝ, V., 1955: Staré Město. Velkomoravské pohřebiště „Na valách“- Staré Město - Die grossmährische Begräbnisstätte „Na valách“. Praha.

HRUBÝ, V.-HOCHMANOVÁ, V.-PAVELČÍK, J., 1955: Kostel a pohřebiště z doby velkomoravské na Modré u Velehradu, ČMMZ XL, 42-126.

CHORVÁTHOVÁ, H., 1998: K významu príveskov - amuletov z včasnostredovekých pohrebísk, Hieron 3, 106-112.

- 1998a: K významu lunicových príveskov z včasnostredovekých pohrebísk strednej Európy, Praehistorica XXIII, 135-140.

- 2015: Chronológia ženského honosného šperku vo včasnom stredoveku a jeho historický význam - The Chronology of the beautiful woman jewellery in the Early Middle Ages and its historical significance. Nepubl. dizertačná práca na FF UK v Praze.

CHROPOVSKÝ, B., 1957: Slovanské pohrebisko z 9. stor. vo Vel'kom Grobe - Ein slawisches Gräberfeld aus dem 9. Jahrhundert in Vel'ký Grob, Bezirk Senec, SlArch V, 170-239.

- 1962: Slovanské pohrebisko v Nitre na Lupke - Das slawische Gräberfeld in Nitra auf Lupka, SlArch X, 175-240.

- 1978: Pohrebisko z 9.-10. storočia v Nitre pod Zoborom - Gräberfeld aus dem 9.-10. Jahrhundert in Nitra am Fuß des Zobor, SlArch XXVI, 99-125.

IŽÓF, J., 1984: Záchranné výskumy múzea v Galante. In: AVANS 1983, 93-94. Nitra.

JELÍNKOVÁ, D., 1999: Slovanské pohřebiště z 9. až 12. století v Mušově. Katalog. Brno.

KLANICA, Z., 1985: Mikulčice-Klášteřisko, PA LXXVI, 474-539.

- 2006: Nechvalín, Prušánky. Čtyři slovanská pohřebiště. Díl II. - Nechvalín, Prušánky. Vier slawische Nekropolen, Teil II. Spisy ARÚ AV ČR Brno 28 (Kouřil, P., ed.). Brno.

- 2006a: Nechvalín, Prušánky. Čtyři slovanská pohřebiště. Díl I. - Nechvalín, Prušánky. Vier slawische Nekropolen, Teil I. Spisy ARÚ AV ČR Brno 28 (Kouřil, P., ed.). Brno.

KOVRIG, I., 1963: Das awarenzeitliche Gräberfeld von Alattyán. Archaeologia Hungarica, Series Nova 40. Budapest. 
KRASKOVSKÁ, L', 1950: Príspevok k pohrebným zvykom starých Slovanov (Staroslovanské pohrebište vo Vel'kom Grobe), Historický ZbSNM VIII, 43-49.

- 1953: Slovanské pohrebište v Devíne v polohe Staré vinohrady, AR V, 171-173.

- 1965: Slovanské pohrebisko v Kopčanoch - Slawisches Gräberfeld in Kopčany, ZbSNM LIX, História 5, 19-49.

KRASKOVSKÁ, L'.-PAULÍK, J., 1978: Vel'komoravské pohrebisko v Tvrdošovciach - Großmährisches Gräberfeld in Tvrdošovce, ZbSNM LXXII, História 18, 83-119.

KUBÁLEK, P.-STOLZ, D.-SASKOVÁ, L.-VANĚK, D., 2008: Blízkovýchodní haplotyp u pohřbu mladého muže s rozštěpem lebky z raně středověkého pohřebiště na Tetíně - A near eastern haplotype in the burial of a young man with a fissure in the skull from the early medieval cemetery at Tetín, ASČ 12, 645-650.

LESÁK, B.-MUSILOVÁ, M., 1999: Hrobové celky z druhej polovice 9. až prvej polovice 10. stor. na území ŠPMR Bratislava, Studia Archaeologica Slovaca Mediaevalia II, 33-61.

MAREŠOVÁ, K., 1983: Uherské Hradiště-Sady. Staroslovanské pohřebiště na Horních Kotvicích - Altslawische Begräbnisstätte in Uherské Hradiště-Sady. Brno - Uherské Hradiště.

MĚŘÍNSKÝ, Z., 1985: Velkomoravské kostrové pohřebiště ve Velkých Bílovicích - Das grossmährische Skelettgräberfeld bei Velké Bílovice. Studie AÚ Brno XII. Praha.

MJARTAN, J., 1953: Vampírske povery v Zemplíne, Slovenský národopis I, 107-134.

PLACHÁ V.-HLAVICOVÁ J.-KELLER I., 1990: Slovanský Devín - Das Slawische Devín. Bratislava.

POULÍK, J., 1955: Nález kostela z doby ř́iše velkomoravské v trati „Špitálky“ ve Starém Městě - Die Entdeckung der zweiten Kirche in Staré Město (Alt-Stadt) in Süd-Ostmähren, PA XLVI, 307-351.

- 1957: Výsledky výzkumu na velkomoravském hradišti „Valy“u Mikulčic. I. zpráva za r. 1954-1956 - Die Ergebnisse der Ausgrabungen auf dem grossmährischen Burgwalle „Valy“ bei Mikulčice. I. Bericht für das Jahr 1954/56, PA XLVIII, 241-388.

- 1963: Dvě velkomoravské rotundy v Mikulčicích - Zwei grossmährische Rotunden. Praha.

PROFANTOVÁ, N.-KAVÁNOVÁ, B., 2003: Mikulčice - pohřebiště u 6. a 12. kostela - Mikulčice - Gräberfeld bei der 6. und 12. Kirche. Spisy ARÚ AV ČR v Brně 22 (Kouřil, P., ed.). Brno.

PŘICHYSTALOVÁ, R., 2010: Nerituálny pohreb muža z južného predhradia na Pohansku pri Břeclavi Die Sonderbestattung eines Mannes aus der südlichen Vorburg in Pohansko bei Břeclav. In: Zaměřeno na stř̌edověk. Zdeňkovi Měřínskému k 60. narozeninám (Ungerman, Š.-Přichystalová, R., edd.), 139-150. Praha.

- 2011: Problematika pohřbívání na Jižním předhradí velkomoravského hradiska Břeclav - Pohansko - The Burial Issues in Southern Bailey of Greatmoravian Stronghold Pohansko near Břeclav. Nepubl. dizertačná práca na FF MU, Brno.

PŘICHYSTALOVÁ, R.-KALÁBEK, M., 2014: Raněstředověké pohřebiště Olomouc -Nemilany - Das frühmittelalterliche Gräberfeld von Olomouc - Nemilany. Katalog. Brno.

REJHOLCOVÁ, M., 1992: Vel'komoravské pohrebisko v Lefantovciach - Ein grossmährisches Gräberfeld in Lefantovce, ŠZ 28, 251-276.

- 1995: Pohrebisko v Čakajovciach (9.-12. storočie) - Das Gräberfeld von Čakajovce (9.-12. Jahrhundert). Katalóg. Nitra.

STAŇA, Č., 2006: Velkomoravská pohřebiště v Rajhradě a Rajhradicích. Katalog - Großmährische Gräberfelder in Rajhrad und Rajhradice. Brno.

STLOUKAL, M. et al., 1999: Antropologie. Př́ručka pro studium kostry. Praha.

STLOUKAL, M.-HANÁKOVÁ, H., 1985: Antropologický materiál z pohřebiště Mikulčice-Klášteřisko Anthropologisches Material aus dem Gräberfeld Mikulčice-Klášteřisko, PA LXXVI, 540-588.

SZÖKE, B.-NEMESKÉRI, J., 1954: Archeologické a antropologické poznatky z výskumu v Bešeňove pri Šuranoch - A Bešeňov (Zsitvabesenyő) - Papföldi őskori és 11.-12. századi temető, S1Arch II, 105-126.

ŠTEFAN, I., 2009: Frühmittelalterliche Sonderbestattungen in Böhmen und Mähren. Archäologie der Randgruppen?, Ethnographisch-Archäologische Zeitschrift 50, 139-162.

TOČÍK, A., 1971: Flachgräberfelder aus dem IX. und X. Jahrhundert in der Sudwestslowakei, SlArch XIX, $135-276$.

UNGER, J., 2006: Pohřební ritus 1. až 20. století v Evropě z antropologicko-archeologické perspektivy. Brno.

UNGERMAN, Š., 2005: Ženský šperk staršího velkomoravského horizontu - Frauenschmuck des älteren großmährischen Horizonts, AR LVII, 707-749.

- 2007: Raně středověké pohřebiště v Dolních Věstonicích-Na pískách. Nepubl. Dizertačná práca na FF MU, Brno. 
UNGERMAN, Š.-KAVÁNOVÁ, B., 2010: Das Gräberfeld bei der Basilika von Mikulčice. In: Frühmittelalterliche Kirchen als archäologische und historische Quelle. Internationale Tagungen in Mikulčice VIII (Poláček, L.-Maříková-Kubková, J., edd.), 71-86. Brno.

VENDTOVÁ, V., 1962: Slovanské pohrebisko v Ladiciach, okr. Nitra - Slawisches Gräberfeld in Ladice, Bezirk Nitra, AR XIV, 381-404.

- 1969: Slovanské osídlenie Pobedima a okolia - Die slawische Besiedlung von Pobedim und Umgebung, SlArch XVII, 119-224.

VONDRÁKOVÁ, M.-HANULIAK, M., 2006: Výnimočné formy polôh telesných zvyškov pochovaných v Malých Kosihách - Exceptional forms of bedding of bodies buried in Malé Kosihy from the viewpoint of anthropology. In: Ve službách archeologie VI (Hašek, V.-Nekuda, R.-Ruttkay, M., edd.), 369-380. Brno.

ZÁBOJNÍK, J., 1985: Výskum včasnostredovekého pohrebiska v Cíferi-Páci - Grabung auf einem frühmittelalterlichen Gräberfeld in Cífer-Pác, ŠZ 21, 205-216.

\section{Zusammenfassung}

\section{Bestattungsanomalien auf mittelalterlichen Gräberfeldern - eine Randgruppenerschei- nung der Bevölkerung?}

In dem vorliegenden Beitrag beschäftigen wir uns mit anomalen Gräbern aus dem 9.-12. Jahrhundert auf dem Gebiet der Südwestslowakei und Mährens. Während dieser Zeit dominierte eine ausgestreckte Rückenlage mit neben dem Körper liegenden Armen und einer West-Ost-Orientierung (Hanuliak 2004, 44). Ausnahmen bilden Gräber von Individuen, die in Bauch- oder Seitenlage, bzw. mit einer anderen Orientierung bestattet wurden. Diese Abweichungen befinden sich auf mehreren Gräberfeldern und sind keine Einzelerscheinung. Insgesamt wurden auf 96 Gräberfeldern atypische Gräber verzeichnet und 714 solcher Gräber entdeckt.

Den geringsten Anteil an anomalen Gräbern nehmen Gräber mit in Bauchlage bestatteten Individuen ein. Insgesamt wurden 34 auf diese Weise bestattete Individuen entdeckt, wobei die Grabgruben auf dem Gräberfeld keine besondere Lage hatten, bzw. auch nicht speziell hergerichtet waren. Unter den Individuen dominierten Frauen (Abb. 4) und Individuen zwischen 30 und 40 Jahren (Abb. 5). Inventar wurde lediglich in vier Gräbern gefunden.

In Seitenlage bestattete Individuen wurden an 44 Fundstellen entdeckt und machten 216 der Fälle aus. So wie im Falle der in Bauchlage bestatteten Individuen waren auch sie nicht isoliert, und ihre Gräber wiesen ebenfalls keine spezielle Konstruktion auf. Unter den auf diese Weise bestatteten Personen haben die Frauen leicht dominiert (Abb. 7), das Verhältnis zwischen Erwachsenen und Kindern ist ausgeglichen. Ungefähr in einem Viertel der Gräber wurde Inventar gefunden.

In 264 Fällen entdeckte man in Nordsüd- und Südnordrichtung orientierte Individuen. Das Verhältnis zwischen Frauen und Männern in dieser Kategorie ist ausgeglichen (Abb. 11), erwähnenswert ist jedoch, dass in den jüngeren Kategorien fast ausschließlich Frauen eine Orientierung in diese Richtung aufwiesen, ab der Alterskategorie Maturus II dominieren Männer (Abb. 12).

Die häufigsten Anomalien bei mittelalterlichen Bestattungen waren Individuen, die in Ostwestrichtung orientiert waren, d.h. sie wurden umgekehrt wie die meisten anderen bestattet. Insgesamt wurden 432 Individuen auf 66 Gräberfeldern entdeckt. Männer und Frauen sind zu gleichen Teilen vertreten, auch die Anzahl der Erwachsenen und Kinder ist ausgeglichen. Im Inventar kamen auch Gräber mit einer Ausstattung vor, die über den Standard hinausging. Bei den in atypischer Lage oder Orientierung gefundenen Individuen, bzw. bei den durchgeführten anthropologischen Analysen konnten fast keine körperlichen Gebrechen oder Krankheiten festgestellt werden, worauf ihre Lage hätte zurückgeführt werden können. Wenn irgendwelche am Skelett erkennbare Zeichen für Krankheiten auf den Gräberfeldern auftraten, hatten auch die regulär bestattete Individuen daran gelitten.

Aufgrund der oben genannten Erkenntnisse kann demnach nur bei in Bauchlage bestatteten Individuen, bei denen die Frauen dominierten, ein gewisses Schema hergeleitet werden. 
Unserer Auffassung nach sollte die Betonung immer auf einen konkreten Fund und auf den Kontext gelegt werden, in dem dieser gefunden wurde. Als Beispiel sei hier Grab 226 in Čakajovce aufgeführt, in welchem eine Frau mit einem schlangenförmigen Anhänger (nach Ungerman 2005, 730) und Mosaikperlen sowie in Südost-Nordwest-Richtung bestattet wurde, deren Grab sich ursprünglich am Rande des Gräberfeldes befand und die in der Gemeinschaft die Funktion einer „Wahrsagerin“ gehabt haben könnte. Auf diesem Gräberfeld ist auch bemerkenswert, dass die meisten Grabgruben mit Individuen in Ost-West-Richtung eine überdimensionierte Größe hatten. Demnach hatten sie gerade wegen ihrer Außergewöhnlichkeit umgekehrt, als imaginäre Führer bestattet werden können.

Die vorliegende Studie wurde im Rahmen des Projekts 2/0044/14 der Förderagentur VEGA: Die materielle Kultur und ihr Beitrag zur Rekonstruktion des irdischen Lebens und der Begräbnisbräuche in der mittelalterlichen Sozietät ausgearbeitet.

Mgr. Lucia Nezvalová, Archeologický ústav SAV, Akademická 2, SK 94921 Nitra, Slovenská republika, nezvalovalucia@gmail.com 